\title{
Non-Pecuniary Damages before the European Court of Human Rights: Forget the Victim; it's all about the State
}

\begin{abstract}
Veronika Fikfak ${ }^{1}$
This paper studies how the European Court of Human Rights adjusts damages for human rights violations. The paper empirically analyses 13 years of ECtHR's case-law in relation to Articles 2 (right to life), 3 (torture, inhuman and degrading treatment) and 5 (arbitrary detention) of the Convention. The goal is to understand whether the statements made by the Court about the aims pursued through just satisfaction are confirmed in practice. Through an empirical quantitative study relating to non-pecuniary damages, the paper quantitatively analyses the practice of the Court in awarding non-pecuniary damages for human rights violations and compares it to the competing visions of the ECtHR's function. In particular, I am interested in determining whether just satisfaction is aimed at redressing the suffering of the victim, her circumstances and vulnerability, or whether the focus is more on the respondent state, its conduct and its past human rights record. The answers to these questions will contribute to the debate whether the ECtHR's role is one of delivering 'individual justice' or whether the Court is - as an international court enforcing an international treaty - focused on the 'state'.
\end{abstract}

Cite as: Fikfak V. Non-pecuniary damages before the European Court of Human Rights: Forget the victim; it's all about the state. (2020) Vol 33. Leiden Journal of International Law, 134. https://doi.org/10.1017/S0922156520000035

The copy-edited version of this article has been published in the Leiden Journal of International Law (LJIL) and can be found online at journals.cambridge.org/ljil

\footnotetext{
${ }^{1}$ Associate Professor, University of Copenhagen/Senior Lecturer, University of Cambridge, Homerton College. This paper was written whilst I was still based at Cambridge and I am grateful to the UK's ESRC Future Research Leaders grant (ES/N000927/1), the Isaac Newton Trust, and the Cambridge Humanities Research Grant for helping fund the work on this project. Sabrina Boudra, Jaka Kukavica, and Donata Szabo coded the data. The paper was edited upon transfer to the University of Copenhagen, iCourts, the Centre of Excellence for International Courts, established through funding from Danish National Research Foundation Grant no. DNRF105.

Throughout the early stages of the project Professor Mandeep Dhami mentored me in empirical analysis and aided with the initial modelling and data preparation, as well statistical analysis in relation to Article 3. I am grateful to all. During the past three years, this paper was presented at the NYU Junior Faculty Forum and at a number of other venues in the UK and around Europe. I am grateful to all participants for their invaluable feedback. Most of all, I am grateful to judges and members of the Registry who took their time and spoke to me freely about the practice of the Court. Their anonymity is protected through random numbering. The case law is generated from the HUDOC database CCouncil of Europe/European Court of Human Rights - Conseil de l'Europe/Cour européenne des droits de l'homme. The analysis presented in this paper formed the basis for papers I have already published and which I refer to throughout this paper: V. Fikfak 'Changing State Behaviour: Damages before the European Court of Human Rights, EJIL (2018), Vol. 29 No. 4, 1091-1125. The regression results and coding tree can be found in the Annex, more on the project at www.humanrightsnudge.com.
} 
In 2013, the UK Supreme Court ruled that in a case involving a loss of liberty the compensation awarded by the Court of Appeal should be reduced from $£ 10,000$ to $£ 6,500$ because 'it appears ... that an award in the region of $£ 6,500$ would adequately compensate Mr Faulkner.' 2 The decision in Faulkner had come on the back of a series of cases in which the English courts decided that the domestic approach to human rights damages should 'mirror' the approach of the European Court of Human Rights. ${ }^{3}$ Since the aim of incorporating the Convention 'was not to give victims better remedies at home than they could recover in Strasbourg but to give them the same remedies without the delay and expense of report to Strasbourg' ${ }^{4}$. English courts adopted the same approach as Strasbourg: they adjusted the quantum to ECtHR judgments. Since before the Strasbourg court the awards for 'just satisfaction' were on the 'low side' 5 compared to the normal damage awards in the UK, they lowered compensation awarded by the Court of appeal, justifying their award with the phrase that the amount would 'adequately compensate' the applicant. No other reasons were given for the award nor explanations about the specific circumstances of the case or characteristics of the victim that may have been taken into account in the determination of the award.

The approach of the UK Supreme Court in Faulkner to the determination of just satisfaction should not come as a surprise. The case law of the European Court of Human Rights in relation to just satisfaction has been cloaked in mystery. Judgments of the Court regularly provide only the briefest of justifications for the award: 'Making its assessment on an equitable basis, the Court awards...' ${ }^{6}$ or 'Having regard to the relevant circumstances of the present case and ruling on an equitable basis..." Although there are rumours that the Court is using a set of tables to determine the amounts and maintain consistency, ${ }^{8}$ the Court has refused to publish these since this would limit the inherent discretionary nature of the award and would lead to additional disputes regarding expected sums. ${ }^{9}$ Some have interpreted this refusal as proof that no tables exist and that the amount of the award is determined on a case-by-case basis, 'often without considering or distinguishing cases involving similar facts'. ${ }^{10}$ Already in 2001, the Law Commission - the law reform body for England and Wales - criticised the Court's approach as arbitrary and lacking in transparency. ${ }^{11}$ Others have argued that damages are awarded intuitively. ${ }^{12}$ They have accused the Court that instead of adopting a clear approach, the lack of reasoned decisions articulating principles on which a remedy is afforded makes the work of

\footnotetext{
2 [2013] UKSC 23, [87].

${ }^{3}$ Ullah [2004] UKHL 26.

${ }^{4}$ Faulkner (n 2), [28], referring to $R$ (Greenfield) v Secretary of State for the Home Department [2005] 1 WLR 673.

5 ibid., [27].

${ }^{6}$ Ushakov v Russia, app. 10641/09, 25 October 2011.

${ }^{7}$ Jashi v Georgia, app. 10799/06, 8 January 2013.

${ }^{8}$ Cocchiarella v Italy, app. 64886/01, 9 March 2006.

${ }^{9}$ D. Harris, M. O'Boyle, E. Bates, and C. Buckley. Law of the European Convention on Human Rights (Oxford, OUP 2014) 156.

${ }^{10}$ The Law Commission. "Damages Under the Human Rights Act 1998 - Report”, (2001) Cm 4853, SE/2000/182; P. Leach. "Access to the European Court of Human Rights - From a Legal Entitlement to a Lottery", (2006) 27 HRLJ 11-25.

${ }^{11}$ Law Commission (ibid).

${ }^{12}$ Franz Bydlinski, 'Methodological Approaches to the Tort Law of the ECHR', in Attila Fenyves, Ernst Karner, Helmut Koziol \& Elisabeth Steiner eds., Tort Law in the Jurisprudence of the European Court of Human Rights (De Gruyter, 2011) 176; C. Kissling \& D. Kelliher, 'Compensation for Pecuniary and Non-Pecuniary Loss', in ibid., 579; O. Ichim, Just Satisfaction under the European Convention on Human Rights 121 (CUP, 2015).
} 
practitioners and national judges seeking to apply the ECtHR approach across Member States difficult. $^{13}$

As Faulkner shows, the ECtHR's refusal to set out any rules or guidelines as to when individuals are likely to get compensation or indeed which elements of their treatment might affect the ultimate award provides little opportunity to English courts to bolster mechanisms to remedy human rights violations at home. ${ }^{14}$ As an international court responsible for interpreting the Convention and ensuring that Member States abide by obligations set out there, the case law of the ECtHR affects the laws and practice of 47 states. Every one of these countries is bound to comply with decisions of the Court and enforce human rights appropriately on the domestic level. Yet, the uncertain practice of the ECtHR provides little clarity as to how nonpecuniary damage ought to be determined. If the European human rights system seeks to change the behaviour of states by encouraging them to embed the protection of the Convention into their domestic legal systems, then in the context of damages such internalisation might lead to a perverse situation where it could perpetuate or even encourage the lack of clarity on the part of domestic judges. In the UK, a two-tier system is now in place, where damages under tort law considerably outweigh human rights awards. ${ }^{15}$ Whilst the rules relating to the former are clear, no one knows how human rights awards are determined. As judges assert, 'we have no principles' to apply. ${ }^{16}$

Given the impact of the practice of the ECtHR case law on jurisdictions which have embedded the Convention into their own legal systems and the immense legal gap that exists both on the international and domestic level, it is high time to elucidate the practice of the Court in relation to just satisfaction. A first empirical study that sought to fill this gap was published a couple of years ago, when scholars from Max Planck Institute found that the 'frequently voiced academic reproach that the Court's practice is arbitrary or unprincipled' is incorrect. They found that the Court does follow the hierarchy (or 'ranking') inherent in the Convention and awards higher damages for absolute rights violations compared to procedural breaches. ${ }^{17}$ However, the study only investigated a year of the Court's practice ${ }^{18}$ and apart from the 'ranking' did not identify other variables that may affect the determination of damages. It is still unclear, for example, whether the just satisfaction is aimed at redressing the suffering of the victim, affirming his or her rights under the Convention, or whether it is aimed at governments

\footnotetext{
${ }^{13}$ J. Beatson, S. Grosz, T. Hickman, R. Singh, S. Palmer. Human Rights: Judicial Protection in the United Kingdom (London, Sweet and Maxwell, 2008); L. Lester, D. Pannick and J. Herberg. Human Rights Law and Practice (London, LexisNexis $3^{\text {rd }}$ edition, 2009).

${ }^{14}$ Generally L Helfer, Redesigning the European Court of Human Rights: Embeddedness as a Deep Structural Principle of the European Human Rights Regime (2008) 19 EJIL 125-159. On the particularities of the internalisation of the ECHR by English courts, V. Fikfak 'English Courts and the 'internalisation' of the European Convention on Human Rights - Between Theory and Practice.' (2013-2014) 5 Cambridge Journal of International and Comparative Law - The UK Supreme Court Yearbook (April 2015) 183; 'International Law Before English and Asian Courts: Finding the Judicial Role in the Separation of Powers', Asian Journal of International Law, 3(2), 271; and Burnett B. et al, 'Domestic Courts' Reading of International Norms: A Semiotic Analysis', Int J Semiot Law (2009) 22: 437.

15 J Varuhas. Damages for Breaches of Human Rights (Oxford, Hart Publishing 2016).

${ }^{16}$ Some judges recognise this, saying 'We have no principles'. Others responded: 'We have principles, we just do not apply them.' See D Shelton, Remedies in International Human Rights Law (Oxford, OUP 3rd edition, 2015) 2. Though it should be noted that individual judges are hard at work to try and distil principles from ECtHR's jurisprudence (see Lord Reed and Carnwath in Faulkner).

${ }^{17}$ S Altwicker, T. Altwicker, A Peters. 'Measuring Violations of Human Rights: An Empirical Analysis of Awards in Respect of Non-Pecuniary Damage Under the European Convention on Human Rights' Zeitschrift für ausländisches öffentliches Recht und Völkerrecht (ZaöRV)/Heidelberg Journal of International Law (HJIL) 76 (2016), 1-51, 43.

${ }^{18}$ The choice of the year was also problematic (2006), since this is supposedly the year in which just satisfaction Unit sought to change/standardise the Court's approach to damages. Harris (n 9) 156.
} 
and intended to primarily act as a 'serious and effective means of dissuasion' of repetitive unlawful conduct. ${ }^{19}$ These questions are not merely about which variables potentially affect the Court's approach to damages. Instead, they go to the very heart of the Court's identity.

Ever since its inception and the drafting of the Convention, there has been a serious tension between two visions of the purpose of the European Convention on Human Rights. One perspective views as the soul of the Convention 'the entitlement of each and every complainant to examination of his or her complaint and, if it is upheld, to individualized relief.' 20 From this perspective, the Court's mission is to hear every individual complaint and focus the proceedings before the Court on the victim of the violation and the vindication of his or her right. The other perspective sees the mission of the Court as enforcing the Convention as the 'constitutional instrument of the European public order'. ${ }^{21}$ In this regard, the ECtHR judgments seek to raise the general standard of protection of human rights in the country concerned and across the community of states by correcting the defects in the national approaches of Member States. From this 'constitutional justice' perspective, the role of the Court is mainly 'corrective' and focused on the state, rather than the victim.

These two competing visions have been debated every time that a new reform of the Convention system is proposed. ${ }^{22}$ For example, when the new pilot procedure was introduced in 2008, as a solution to the Court's increasing work load, it was welcomed because it allowed the Court to summarily deal with hundreds of repetitive claims against a respondent state and require that the state adopt legislative and administrative measures to address the systemic problem. Yet, advocates of individual justice argued that the Court had to look beyond the numbers to ensure that the Court's new admissibility criteria would not lead to well-founded applications being dismissed without sufficient review. ${ }^{23}$ In the end, both proponents of the constitutional and individual justice 'were positive in their reception of the pilot judgment mechanism. ${ }^{24}$ It represented a good compromise between a more constitutional role for the Court 'ordering member states to adopt general measures', whilst still preserving a forum for individuals' claims to be heard. ${ }^{25}$

Whilst this old debate is reignited anytime a new reform of the Convention system is proposed, there is little if any discussion on how it has affected the Court's handling of damages and in particular, its approach to non-pecuniary damages. From the individual justice perspective, the primary function of damages is presumably to address the harm done to the victim. If the applicant has suffered 'evident trauma', 'pain and suffering, distress, anxiety', they should be compensated for their suffering and placed in the same position as they would be had no injury occurred. ${ }^{26}$ In contrast, for constitutionalists the remedies adopted by the Court should be such as to motivate and incentivise the state to change its behaviour and avoid future repet-

\footnotetext{
${ }^{19}$ Guiso-Gallisay v Italy, app. 58858/00, 22 December 2009, [85].

${ }^{20}$ P. Mahoney "New Challenges for the European Court of Human Rights Resulting from the Expanding Case Load and Membership," (2002) 21 Penn State International Law Review 101, 104.

${ }^{21}$ Loizidou v. Turkey, 310 ECtHR, Series A No 310 (1995), at 27.

${ }^{22}$ Mahoney (n 20) 101; Luzius Wildhaber, 'A Constitutional Future for the European Court on Human Rights?' (2002) 23 HRLJ 161.

${ }^{23}$ J Gerards, 'Inadmissibility Decisions of the European Court of Human Rights: A Critique of the Lack of Reasoning' (2014) 14 Human Rights Law Review 148.

${ }^{24}$ D. Kurban, 'Forsaking Individual Justice: The Implications of the European Court of Human Rights' Pilot Judgment Procedure for Victims of Gross and Systematic Violations' (2016) 16 Human Rights Law Review 731, 735.

25 ibid.

${ }^{26}$ Barberà, Messegué and Jabardo v Spain, app 10590/83, 13 June 1994, [16], following Ringeisen v Austria, app. 2614/65, 22 June 1972, [21].
} 
itive conduct. Just satisfaction for example could act as a 'serious and effective means of dissuasion with regard to the repetition of unlawful conduct of the same type'. ${ }^{27}$ In this regard, the Council of Ministers and the Parliamentary Assembly of the Council of Europe have explicitly supported the use of punitive damages against states to ensure the effectiveness of ECtHR judgments. ${ }^{28}$

These two visions reveal very different conceptions of the identity and role of the European Court of Human Rights as one of the most important and influential human rights courts in the world. One vision sees it focusing on the victim, the other on the state. Each of these requires a very different approach to monetary damages. In particular, the determination of what constitutes 'just' in the phrase 'just satisfaction' necessitates an answer to the question who is at the centre of the determination of monetary damages - the individual victim or the perpetrator state. ${ }^{29}$ This paper aims to answer this question. It empirically analyses 13 years of ECtHR's case-law in relation to Articles 2 (right to life), 3 (torture, inhuman and degrading treatment) and 5 (arbitrary detention) of the Convention. The goal is to understand whether the statements made by the Court about the aims pursued through just satisfaction are confirmed in practice. Through an empirical quantitative study relating to non-pecuniary damages, the paper will quantitatively analyse the practice of the Court in awarding non-pecuniary damages for human rights violations and compare it to the competing visions of the ECtHR's function. In particular, I am interested in determining whether just satisfaction is aimed at redressing the suffering of the victim, her circumstances and vulnerability, or whether the focus is more on the respondent state, its conduct and its past human rights record. The answers to these questions will contribute to the debate whether the ECtHR's role is one of delivering 'individual justice' or whether the Court is - as an international court enforcing an international treaty focused on the 'state'.

\section{COMPETING VISIONS OF THE ECTHR's FUNCTION}

Article 41 of the ECHR provides that

If the Court finds that there has been a violation of the Convention or the Protocols thereto, and if the internal law of the High Contracting Party concerned allows only partial reparation to be made, the Court shall, if necessary, afford just satisfaction to the injured party.

The requirement for just satisfaction to be awarded are therefore (i) a finding of a violation, (ii) internal law allows only partial reparation and (iii) if necessary to afford just satisfaction. ${ }^{30}$

The first pre-condition is straightforward. ${ }^{31}$ The second is of no more than historical significance for the Strasbourg Court. In some of the early cases, there were suggestions that, even after a finding of violation, these words imposed a limit on the Strasbourg Court's jurisdiction to consider just satisfaction until the extent of reparation under the domestic law had

\footnotetext{
${ }^{27}$ Guiso-Gallisay v Italy (n 19).

${ }^{28}$ Council of Europe (Parliamentary Assembly), Execution of Judgments of the European Court of Human Rights, Doc. 8808 (2000), para. 94.

29 J. Varuhas. "A Tort-Based Approach to Damages under the Human Rights Act 1998", (2009) 72 Modern Law Review 750-782; D. Feldman. "Remedies for Violations of Convention Rights under the Human Rights Act", (1998) European Human Rights Law Review 691.

${ }^{30}$ Guzzardi v Italy, app. 7367/76, 6 November 1980, [114].

${ }^{31}$ Butsee Caballero v United Kingdom, app. 32819/96, 8 February 2000, for the application of Article 41 where liability is conceded, so that there is no actual "finding" of a violation.
} 
been fully explored. ${ }^{32}$ In practice, however, the 'partial reparation' test is easily satisfied, and the Court has reserved for itself jurisdiction to consider the question of just satisfaction in virtually all cases where a violation is found. ${ }^{33}$ Having found a violation, the Strasbourg Court has been willing to grant a remedy without requiring the applicant to return to the domestic system. ${ }^{34}$ Even when the first two pre-conditions are met, an award of damages will not be made unless the Court considers that it is 'necessary' to afford just satisfaction to the injured party. This final requirement gives the Strasbourg Court a wide discretion to determine when an award of damages should be made. ${ }^{35}$ Damages are not available as of right. In practice, the Court has 'frequently [held] that the finding of a violation is sufficient satisfaction without any further award.' ${ }^{36}$ Even if a violation has been established, therefore, an award of damages is not guaranteed. Instead, the applicant will have to have suffered some loss and the intensity of his suffering will have to be such as to 'justify an award of compensation for non-pecuniary damage. ${ }^{37}$

The phrasing of Article 41 accords great discretion to the Court and imposes few, if any, limits on the Court's powers. The choice of terminology by the drafters ('satisfaction') appears to even further contribute to the Court's extensive powers. In the ILC Articles of State Responsibility, the term 'satisfaction' requires that the offending state provide satisfaction for the injury caused by that act insofar as it cannot be made good by restitution or compensation. At first sight, therefore, 'satisfaction' appears to be differentiated from monetary damages and may consist in an acknowledgement of the breach, an expression of regret, a formal apology or another appropriate modality. ${ }^{38}$ In this sense, 'satisfaction' under the Convention could refer to other type of remedies than compensation. Yet, through the case law, the Court has only ever made monetary awards and has only exceptionally required other action from Member States. ${ }^{39}$ Yet, perhaps monetary damages under the heading of 'just satisfaction' may have been used by the Court not primarily for individuals' benefit but as 'punishment of the guilty' and 'assurance as to future conduct... ${ }^{40}$ The choice of the terminology - together with the Court's consistent jurisprudence awarding monetary damages - therefore allows for several different interpretations of 'just satisfaction' under the Convention. It enables the Court to pursue either of the aims of individual and constitutional justice.

\footnotetext{
${ }^{32}$ Some judges have argued that today this phrase should be given more emphasis and that the determination of damages would be left to domestic courts. P. Mahoney. "Thinking a Small Unthinkable: Repatriating Reparation from the European Court of Human Rights to the National Legal Order" in Liber Amicorum Luzius Wildhaber: Human Rights - Strasbourg Views (Kehl, 2007) 263-283.

${ }^{33}$ A claim for just satisfaction is viewed, not as an independent procedure, but as a part of an entire claim, of which the question of liability forms the first part: see P van Dijk and GJH van Hoof, Theory and Practice of the European Convention of Human Rights (3rd ed 1998) 241.

${ }^{34}$ De Wilde, Ooms and Versyp v Belgium (No 2) A 14 (1972), 1 EHRR 438, [16], where the court noted that obliging the applicant to return to the domestic courts would mean that “...the total length of the procedure... would scarcely be in keeping with the idea of the effective protection of Human Rights. Such a requirement would lead to a situation incompatible with the aim and object of the Convention...".

${ }^{35}$ Grosz, Beatson and Duffy, Human Rights: The 1998 Act and the European Convention (n 13) 144 on 'broad discretionary exercise.'

${ }^{36}$ A v UK (2009) 49 EHRR 29, [250].

${ }^{37}$ Silver v UK, Series A 67 (1983), 6 EHRR 62, [10].

${ }^{38}$ Art 37 of Articles of State Responsibility.

${ }^{39}$ Volkov v. Ukraine, Appl. no. 21722/11, Judgment of 9 January 2013, where Article 41 was used together with Article 46.

${ }^{40}$ Shelton (n 16) 157.
} 


\section{A. Individual Justice and the Focus on the Victim}

In its case law, the Court has affirmed that 'the primary purpose of the Convention system is to provide individual relief' ${ }^{41}$ Individuals therefore have a right to submit an application directly to the European Court of Human Rights and to receive a binding determination from the Court of whether the facts presented constitute a violation of their rights and finally, they may be entitled to a remedy to address this breach. ${ }^{42}$ The focus on the individual and his or her right therefore 'lies at the heart of the European regional system for the protection of human rights. ${ }^{43}$

Such focus on the victim requires a very specific approach to just satisfaction. In her book Remedies in International Human Rights Law, Dinah Shelton sets out a legal framework expressing the functions that damages should play in the context of human rights violations. She notes that in most legal systems, including the international legal system, the primary function of damages is compensatory, that is to address the wrong done to a victim and correct the injustice. When a violation occurs, the balance between the victim and perpetrator is upset and the aim of compensatory justice is to "make the parties equal by the penalty (a judge) imposes, whereby he takes from the aggressor any gain he may have secured. ${ }^{44}$ In this regard, a need arises to establish a new balance between the perpetrator's gain and victim's loss, which involves finding the mean between the loss and gain. ${ }^{45}$ This view comes from the perspective that the two parties - the victim and perpetrator - are equal and that when damage is inflicted by one on the other, the remedy has to restore the victim to the condition they were in before. ${ }^{46}$ When such restitution is not possible, damages offer the 'second best' option to compensate for the loss or harm inflicted.

As Shelton argues, this view appears to have been transposed into the context of human rights, where wrongs are committed against individual victims. The ECtHR, for example, insists that since the Convention seeks to protect 'human rights', all rights-infringing conduct assaults the dignity and equality of the victim. ${ }^{47}$ The Court argues that when the applicant has suffered 'evident trauma', 'pain and suffering, distress, anxiety', the award seeks to 'give recognition to the fact that moral damage occurred as a result of a breach of a fundamental human right ${ }^{\prime 48}$ and to compensate the victim and place them in the same position as they would have been had no injury occurred; in other words, restitutio in integrum. ${ }^{49}$ However, if the nature of the injury suffered is such that it may make it impossible to return to the situation existing prior to the breach, then the only claim the applicant can make is for just satisfaction, ie monetary damages. ${ }^{50}$

In this regard, the Court's Practice Directions state that the Court 'will make an assessment on an equitable basis, having regard to the standards which emerge from its case-law. ${ }^{51}$

\footnotetext{
${ }^{41}$ Karner v. Austria (2004) 38 EHRR 528, [26].

${ }^{42}$ Amnesty International's Comments on the Interim Activity Report: Guaranteeing the Long-Term Effectiveness of the European Court of Human Rights, AI Index: IOR 61/005/2004, February 2004, para. 5.

${ }^{43}$ Ibid.

${ }^{44}$ Aristotle, trans. J.A.K. Thompson as The Ethics (London 1955) 148-9.

${ }^{45}$ Ibid.

${ }^{46}$ E. Weinrib 'Understanding Tort Law' (1989) 23 Val. U.L. Rev. 485.

${ }^{47}$ Shelton (n 16); C. McCrudden 2008. "Human Dignity and Judicial Interpretation of Human Rights" (2008) 19(4) EJIL 655-724.

48 Varnava and others v. Turkey, [App. Nos. 16064/90, 16065/90, 16066/90, 16068/90, 16069/90, 16070/90, 16071/90, 16072/90, 16073/90, (Eur. Ct. H.R. September 18, 2009), para. 224].

${ }^{49}$ Barberà, Messegué and Jabardo v Spain [A 285-C (1994) (just satisfaction), para 16], following Ringeisen $v$ Austria [A 15 (1972), 1 EHRR 504 (just satisfaction), para 21].

${ }^{50}$ Konig v Germany [Series A 36 (1980), 2 EHRR 469 (just satisfaction), para 15].

51 Rules of the Court, Practice Directions, at 60ff, available at
} www.echr.coe.int/Pages/home.aspx?p=basictexts/rules/practicedirections, para 14 . 
The Directions explicitly invite applicants who wish to be compensated for non-pecuniary damage to 'specify a sum which in their view would be equitable'. ${ }^{52}$ As long as the victim's claim is 'equitable', it appears, the compensatory model would allow for the victim's selfassessment of loss to be taken into account in determination of damages.

In the context of compensating the victim for the suffering, the Court looks at the applicant's 'loss'. It looks at whether the victim has suffered psychological harm; ${ }^{53}$ distress $;{ }^{54}$ frustration; ${ }^{55}$ inconvenience; ${ }^{56}$ humiliation; $;{ }^{57}$ anxiety; ${ }^{58}$ loss of reputation; ${ }^{59}$ sense of injustice ${ }^{60}$ and loss of relationship. ${ }^{61}$ In certain situations the degree of loss incurred may be insufficient to justify a monetary award. ${ }^{62}$ This is the case when, for example, an individual applicant has suffered anxiety and frustration as a result of a violation but this is not 'of such intensity that it would in itself justify an award of compensation for non-pecuniary damage' ${ }^{63}$ In establishing whether or not damages will be awarded, the Court is therefore looking for 'situations [in which] the impact of the violation may be regarded as being of a nature and degree to have impinged so significantly on the moral well-being of the applicant as to require something further [than a finding of a violation]. ${ }^{64}$ In the context of torture, which we study below, the Court has underlined that 'even in the most difficult circumstances, ... the Convention prohibits in absolute terms torture or inhuman or degrading treatment or punishment. ${ }^{65}$ In this context, the conduct has to attain a 'minimum level [of severity] if it is to fall within the scope of Article 3. ${ }^{66}$ Once such a violation is established, then a certain level of suffering is assumed as inherent in Article 3 violations and an award seeking to compensate a victim's suffering is highly likely. The same would apply for Article 2 (right to life) and (though to a lesser extent) for Article 5.

If the Court is seeking to compensate the victim for their loss, then we should expect the Court to follow the 'individualisation principle', that is to adjust the amount of compensation 'to the concrete situation of each' victim. ${ }^{67}$ In its judgments, the Court does state that it looks to 'all the circumstances of the case, such as the duration of the treatment, its physical or mental effects and, in some cases, the sex, age and state of health of the victim, etc. ${ }^{68}$ Yet whilst the Court asserts that these characteristics relating to the applicant may play a role in the determination of the 'minimum level of severity' and establishment of a violation under Article $3,{ }^{69}$ it is unclear whether they affect the level of compensation. Judge de Albuquerque has insisted that this has to be the case and that the compensatory model which puts the victim at the

\footnotetext{
${ }^{52}$ Ibid para 15.

${ }^{53}$ Aydin v Turkey, app.no. 23178/94, 25 September 1997.

${ }^{54}$ Hokkanen v Finland (1994) Series A no. 44.

${ }^{55}$ Van Der Leer $v$ The Netherlands (1990) Series A No. 170.

${ }^{56}$ Olsson v Sweden (No. 2) (1990) Series A No. 250.

${ }^{57}$ Young, James and Webster, app. No. 7601/76, 18 October 1982.

${ }^{58}$ Loper Ostra $v$ Spain (1994) Series A No. 303C.

59 Sakikv Turkey (1998) 26 EHRR 662.

${ }^{60}$ Devlin v United Kingdom (2002) 34 EHRR 43.

${ }^{61}$ W. v United Kingdom (1988) Series A No 136-C.

${ }^{62}$ Law Commission (n 10) [3, 44].

${ }^{63}$ Silver and others $v$ UK, app. No. 5947/72, 24 October 1983, para 10; also see Faulkner v UK, Campbell v UK, Schonenberg $v$ Switzerland, etc.

${ }^{64}$ Varnava (n 48) 224. The idea of a threshold for recovery of damages for non-pecuniary loss was rejected by the Law Commission in its report.

${ }^{65}$ Aksoy v Turkey, app.no. 59741/00, 31 October 2006, [62].

${ }^{66}$ UK v Ireland [1978] EHRR 25, Ser A, [162].

${ }^{67}$ Mironovas $v$ Lithuania, app. No. 40828/12, 8 December 2015.

68 ibid.

${ }^{69} Y v U K$, app.no. 14229/88, 29 October 1992, Report of the European Commission, paras 43-4.
} 
centre of the claim has to adapt compensation depending on the personal circumstances of the applicant. ${ }^{70}$

One particular manner of adjusting the remedy to the victim is to take into account their vulnerability. Noticeably, the Court has taken important steps - through the development of 'positive obligations' to recognise and 'increase human rights protection for some of the most vulnerable people in society. ${ }^{71}$ These include members of younger and elderly applicants, ${ }^{72}$ women, and members of unpopular minorities, who are often 'unprotected by the ordinary democratic process. ${ }^{73}$ The question, however, arises whether this vulnerability is recognised (or taken into account) also when the Court sets damages. A person in detention has been recognised to be automatically 'in a vulnerable situation' whilst in the charge of the state and the authorities have a duty to protect such a person. ${ }^{74} \mathrm{~A}$ disabled or otherwise unhealthy prisoner may for example require special adjustments to be made for them or to be released from jail if such adjustments are impossible. ${ }^{75}$ Commentators insist that in such cases, damages awarded to the applicant for the failure of the state to provide the duty of care to the vulnerable victim ought to be adapted 'to the circumstances of the case'. ${ }^{76}$ In this regard, the individual's personal situation should influence the quantum. In relation to the vulnerability of victims, Ichim, for example, argues that 'if the victim is particularly vulnerable ..., the award will go towards the maximum limit. ${ }^{77}$

\title{
B. Constitutional Justice and the Focus on State's Conduct
}

Whilst no one disputes the Court's assertion that its aim is to provide individual justice, the question that arises is whether this should take priority over the Court's other aims. From the constitutional justice perspective, the mission of the Court is not exclusively limited to individuals, but rather it focuses on

\begin{abstract}
the more general purposes of ensuring that each Convention country puts in place within its own internal legal order effective means for securing the guaranteed rights (subsidiary facet); avoiding repetition of circumstances giving rise to a violation of the guaranteed rights (preventive facet); and welding together a human rights community of nations with shared legal values across the whole mosaic of post-1989 Europe (unifying facet). ${ }^{78}$
\end{abstract}

The pursuit of 'constitutional justice' is therefore an 'attempt' to ensure that the Court selects and adjudicates cases in a manner to most effectively identify, condemn, and resolve violations across the Council of Europe and prevent similar future breaches. The focus is therefore on the respondent state and on addressing the structure or modus operandi of its institutions. In this sense, individual cases through which the court works, serve to elucidate the Convention principles which can be applied by national authorities.

\footnotetext{
${ }^{70}$ Mironovas (n 67).

${ }^{71}$ A Donald, J Gordon and P Leach, 'The UK and the European Court of Human Rights' Equality and Human Rights Commission Research report 83, 110.

${ }^{72} M$ and C. v Romania, app.no. 29032/04, 27 September 2011, para 119.

${ }^{73}$ Ben Emmerson 'The European Court of Human Rights enhances our democracy' The Independent, 8 February 2011.

${ }^{74}$ Esen v. Turkey, no. 29484/95, para 28; Yaz v. Turkey, no. 29485/95, para 30; and Ayşe Tepe v. Turkey, no. 29422/95, 22 July 2003.

${ }^{75}$ Mircea Dumitrescu v Romania app.no. 14609/10, 30 July 2013 (wheelchair); Wenerski v Poland app.no. 38719/09, 24 July 2012 (epilepsy).

${ }^{76}$ Ichim (n 12) 6.5.3.

77 ibid.

${ }^{78}$ Mahoney (n 20) 105.
} 
From this perspective, the aim of remedies used by the Court is not so much to redress the loss suffered by the victim, but to hold the wrongdoer responsible for his conduct and potentially to 'encourage, cajole, and, where necessary, sanction insufficiently resourced or recalcitrant countries to deter human rights violations from occurring' in the future. ${ }^{79}$ There are therefore two aspects to damages - the punitive and the preventive.

As Shelton argues, '[ $\mathrm{t}] \mathrm{he}$ wrong is an essential element'. '[I]t is the rights-infringing wrongful conduct that is the source of a claim' and which triggers the need to provide restitution to the victim through compensation. ${ }^{80}$ The Court has explicitly adopted this approach: it asserts that the 'seriousness of the violation' plays a crucial role in the determination of damages. ${ }^{81}$ In this regard, it pays special attention to how the particular form of state conduct should be qualified. Within Article 3, for example, the Court draws distinctions embodied in the provision: whether the ill-treatment should be qualified as torture, inhuman or degrading treatment. ${ }^{82}$ In particular in relation to torture, the Court has said that, "it was the intention that the Convention with its distinction between torture and inhuman treatment should by the first of these terms attach a special stigma to deliberate inhuman treatment causing very serious and cruel suffering. ${ }^{83}$ Since the victim cannot be 'un-tortured' or ever adequately compensated for her loss, damages in such cases may be used to condemn the act itself, the wrong, and even to impose a penalty on the perpetrator. ${ }^{84}$ In this regard, retributive justice seeks to restore the balance between the wrongdoer and the victim by permitting survivors of human rights abuses who experience deep emotions of anger and hatred an opportunity to see the wrongdoer punished.

The punitive model focuses very clearly on the action of the defendant - the respondent state - and on its conduct. But if damages are to have a deterrent effect, then behavioural economists argue that they have to be sufficiently high or framed retributively, so as to produce an incentive to change noncompliant behaviour. Eisenberg and Engel show, for example, that depending on the amount of damages, actors may be deterred the more uncertain the threat of the sanction and the higher its severity if they were sanctioned in the past. ${ }^{85}$ Both the certainty and the harshness of damages may be at play, as well as players' previous experiences. Therefore, if a respondent state is a repetitive violator and systemically breaches human rights, it would be expected that if the Court wished for damages to a have a deterrent effect, just satisfaction would increase with the number of similar cases, at times perhaps drastically to incentivise the state (through unpredictable judicial approach to damages) to change its conduct. ${ }^{86}$

\footnotetext{
${ }^{79}$ Helfer (n 15) 155.

80 Shelton (n 16) 20.

${ }^{81}$ T.M. and C.M. v Moldova 26608/11, 28 January 2014.

${ }^{82}$ Aydın v. Turkey, 25 September 1997, §§ 83, 84 and 86, Reports 1997-VI; Selmouni v. France [GC];], no. 25803/94, § 105, ECHR 1999V; Dikme v. Turkey;, no. 20869/92, §§ 94-96, ECHR 2000-VIII; and, among recent authorities, Batı and Others v. Turkey, nos. 33097/96 and 57834/00, § 116, ECHR 2004-IV (extracts), and Menesheva v. Russia. , no. 59261/00, § 55, ECHR 2006-III).

${ }^{83}$ Ireland v UK 18 January 1978, Series A No 25 (1979-80) 2 EHRR 25, [167].

${ }^{84}$ Shelton (n 16) 12.

${ }^{85}$ Eisenberg and Engel, 'Assuring Civil Damages Adequately Deter: A Public Good Experiment', 11(2) Journal of Empirical Legal Studies (2014).

${ }^{86}$ Paulo Pinto de Albuquerque and Anne van Aaken, 'Punitive Damages in Strasbourg', in A. van Aaken and I. Motoc (eds), The ECHR and General International Law (2017) 230. I first raised this hypothesis in V. Fikfak 'What price for human rights? Compensation for human rights violations' Impact, Volume 2017, Number 9, November 2017, pp. 6-8(3).
} 
Whilst international law has always made use of the material inducement approach to change state practices ${ }^{87}$ the idea of punitive damages has generally been rejected. Compensation is not intended 'to punish the responsible State, nor ... have an expressive or exemplary character' ${ }^{88}$ In fact, even when a serious breach of an international obligation has occurred, 'the award of punitive damages is not recognized in international law. ${ }^{89}$ Even more, after the International Law Commission made a proposal for damages to reflect the gravity of the breach, the overwhelmingly negative reaction led the Rapporteur to conclude that 'the idea of punitive damages under international law is currently unsustainable' ${ }^{90}$ The ECtHR explicitly accepts this approach and has until now not considered it appropriate to accept claims for damages with labels such as 'punitive', 'aggravated' or 'exemplary'. ${ }^{91}$ As the Court insists: damages 'serve to give recognition to the fact that moral damage occurred as a result of a breach of a fundamental human right and reflect in the broadest of terms the severity of the damage; they are not, nor should they be, intended to give financial comfort or sympathetic enrichment at the expense of the Contracting Party concerned'.$^{92}$ In this sense, the Court has rejected that awards could serve 'some collective interest, such as the public interest in punishing a wrongdoing state or in rendering respect for human rights more effective in general. ${ }^{\prime 93}$

Yet, as De Albuquerque and Van Aaken note, these statements rejecting punitive damages do not mean that the Court may not in practice already be punishing states for certain types of behaviour. ${ }^{94}$ In their article, they list at least seven ways in which the Court has acted punitively, including in Cyprus v Turkey, in which the Court awarded millions in non-pecuniary damages although the exact number of individual victims of human rights violations was not established and the victims in the Karpas region were neither identified nor identifiable on the basis of the evidence in the file. As a consequence - Pinto argues in his concurring opinion - 'the claimant State will be the final beneficiary of the amounts paid by the respondent State. The punitive nature of this compensation is flagrant ${ }^{95}$ Pinto welcomes this approach, underlying that 'punitive damages [are] an appropriate and necessary instrument for fulfilling the Court's mission to uphold human rights in Europe and ensuring the observance of the engagements undertaken by the Contracting Parties in the Convention and the Protocols.' For Pinto this 'conclusion applies with even greater force in the case at hand, where the respondent State not only committed a multitude of gross human rights violations over a significant period of time in northern Cyprus, and did not investigate the most significant of these violations adequately and in a timely manner, but also deliberately failed year after year to comply with the Grand Chamber's judgment on the merits delivered a long time ago with regard to these specific violations. ${ }^{\prime 96}$

The discussion of punitive damages is not limited to Cyprus v Turkey. In Guiso-Gallisay v Italy, the Court explicitly stated that Article 41 awards must be 'a serious and effective means of dissuasion with regard to the repetition of unlawful conduct of the same type, without

\footnotetext{
${ }^{87}$ R. Goodman and D. Jinks, Socializing States: Promoting Human Rights Through International Law (2013) 125.

${ }^{88}$ Commentary to the ILC Articles on State Responsibility 2001, http://legal.un.org/ilc/texts/instruments/english/commentaries/962001.pdf: 99.

89 ibid 111.

90 James Crawford, State Responsibility (CUP 2013) 526.

${ }^{91}$ Practice Directions (n 51) para 9; Akdivar v Turkey, app.no. 21893/93, 1 April 1998; Selçuk and Asker v Turkey, app.no. 23184/94, 24 April 1998.

${ }^{92} \operatorname{Varnava}$ (n 48), para. 224.

${ }^{93}$ Altwicker (n 17) 11.

${ }^{94}$ Pinto and van Aaken (n 87); Fikfak (n 1) EJIL article where I query whether the Court has imposed punitive damages implicitly/covertly.

${ }^{95}$ Cyprus v. Turkey, supra note 25, Concurring Opinion of Judge Pinto de Albuquerque, paras 12-13 (emphasis added).

${ }^{96}$ Ibid., para. 19.
} 
however assuming a punitive function.' ${ }^{97}$ The debate about the introduction of such 'exemplary' or 'aggravated' damages has also been present in the Committee of Ministers. The Committee has previously explicitly supported the use of punitive damages to ensure the effectiveness of ECtHR judgments, as has the Parliamentary Assembly of the Council of Europe, which considered the introduction of fines to be imposed on states that persistently fail to execute the judgments of the Court, with a view to introducing more effective measures in the face of noncompliance. ${ }^{98}$ The issue was debated most recently in relation to the Brighton Declaration, where the UK 'invited the Committee of Ministers to consider the introduction of a financial penalty where a failure to implement a judgment leads to a significant number of repetitive applications to the Court' ${ }^{99}$ However, these proposals did not make it into the final draft.

The images below summarise the two models:
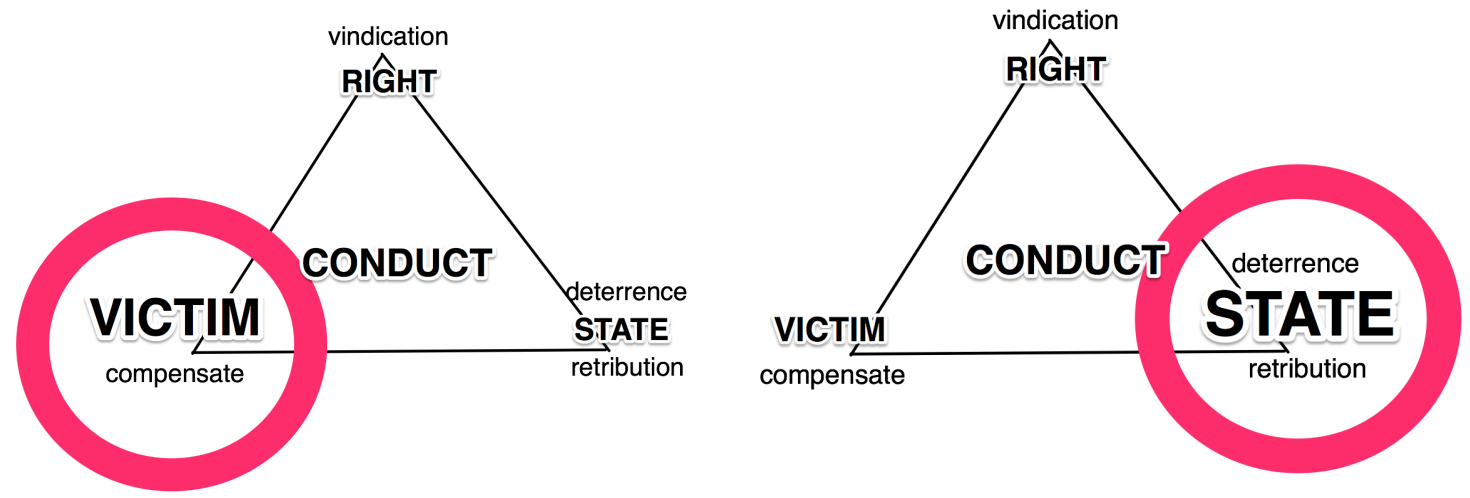

Victim model vs State model

\section{The Data ANd Methodology}

To establish what approach the ECtHR takes to 'just satisfaction', I looked at all cases in which a violation of Article 2 - right to life, Article 3 - torture, inhuman and degrading treatment and Article 5 - arbitrary detention was established between the beginning of 2003 and end of 2015 (13 years). ${ }^{100}$ This resulted in for Article 2: 267 cases, 791 victims; for Article 3: 771 cases, totalling 1128 victims; ${ }^{101}$ and for Article 5: 867 cases, 1247 victims. All the cases analysed are violations of a single article. I therefore excluded cases in which there were violations of more than one article (eg cases in which Article 2, 3, or 5 was found to have been violated in addition to other articles of the Convention). This was done in order to isolate the effect that multiple violations may have on quantum and to be able to see - further down the line - whether the Court adopts a structured approach to different violations which are internal to each article, rather than just distinguishing between different articles. In certain models in the regression

\footnotetext{
${ }^{97}$ Guiso-Gallisay v. Italy (n 19) para 85.

98 Council of Europe (n 28), para. 94.

${ }^{99}$ High Level Conference on the Future of the European Court of Human Rights, Draft Brighton Declaration, 23 February 2012, paragraph 36(d).

${ }^{100}$ At the beginning of this project (January 2016), we initially chose the last 10 years of cases, however, we added additional 3 years (2003-2006) after learning that the Court set out to reform its practice to damages in 2006. (Harris et al 2014, (n 9)). This expanded dataset allows us to try and test whether indeed a shift took place and assess its impact.

${ }^{101}$ I excluded extradition cases because the aim of these cases is to prevent deportation for fear of a potential Article 3 violation and no compensation is awarded. The Court concluded that a finding per se amounted to just satisfaction. See Soering v UK, Chahal v UK, and Ahmed v Austria.
} 
analysis, further victims are missing due to missing data. These are limited to cases in which the age of the applicant was not provided by the Court.

Initially, the study focused only on Article 3. This was for several reasons: first, according to the Court the article enshrines one of the most fundamental values of democratic society. Yet, Article 3 is the second most frequently violated article in the Convention and represents $23 \%$ of the violations established by the Court. ${ }^{102}$ Secondly, the Convention prohibits torture or inhuman or degrading treatment in absolute terms. This means that in comparison to other articles, no proportionality assessment takes place and that a violation of Article 3 takes place irrespective of the victim's conduct. As regards damages, this would suggest that the values protected in the provision are considered highly important. Thirdly, although Article 3 in comparison to the UN Convention against Torture prohibits clearly all three forms of illtreatment, a distinction appears to be drawn between the different degrees of ill-treatment. ${ }^{103}$ The internal hierarchy between the different concepts, in particular between torture and the other violations, may be especially amenable to a statistical analysis and may show the Court's attitude towards different forms of ill-treatment by the state.

In the second stage of the study and after interviews with judges, I have additionally included both Article 2 and Article 5 into the analysis. This was done in order to verify whether the pattern that was identified in the context of torture, inhuman and degrading treatment, can also be confirmed in relation to the other two articles. The three articles are similar in many respects: they relate to physical integrity and are considered to cover the most important aspects of the Convention. Yet, there are also important differences between the articles, ${ }^{104}$ which allow me to test some additional variables. For example, in contrast to Article 3, both Articles 2 and 5 consider the individual's contribution in the context of damages. Adding both to the analysis can therefore permit us to understand whether the victim's contribution to the violation affects the quantum. Secondly, as far as the state as the originator of the violative conduct is concerned, the structure of the data is somewhat different relating to the different articles. In relation to Article 2 (right to life), most of the violations come from new countries (those joined after 1990) or Turkey. In relation to Article 3 and 5, the proportion is more evenly distributed: between 15-19\% of cases come from old countries (those joined ECHR before 1990), 50\% from new countries and around 30\% for Turkey. If the results in the three articles - as far as states are concerned - are similar regardless of the different split between the countries, then the results will be even more robust. ${ }^{105}$

The basic unit of analysis adopted in the paper is the individual victim. If the Court adopts an individualised approach to Convention rights and considers the circumstances of a particular case and the effect a violation may have had on the individual, then the unit of analysis has to be the individual victim. 'Victim' is a technical term relating to the application procedure before the Court. ${ }^{106}$ In order for an individual to be considered a victim, they have to show that they have been directly affected by a measure which arguably led to a violation

\footnotetext{
102 Violations of Article 3 constituted 23\% of all violations found in 2015. Annual report: https://echr.coe.int/Documents/Annual_report_2015_ENG.pdf.; Shelton (n 16) 212. Violations of Article 3 come only after a large percentage of cases concerning procedural delay of justice or lack of due process in violation of article 5 and $6(1)$. These constituted $40 \%$ in 2015 .

${ }^{103}$ UN Convention against torture, 10 December 1983.

${ }^{104}$ One of the differences is that on average, violations of Article 2 and 5 are much less frequent: only $15 \%$ for 2015 for Article 5 and at 7\% for Article 2.

105 Since the study was conducted, the analysis has also been expanded to other articles, including Article 6 (right to a fair trial and length of proceedings). The results have confirmed the relevance of many of the variables studied in this paper. Where relevant, these results are mentioned in footnotes of this article. They will be published in due course.

106 Art. 34 ECHR.
} 
and which is allegedly attributable to the respondent state. ${ }^{107} \mathrm{He}$ or she must also show that the violation has not yet been redressed by the state. ${ }^{108}$

Although my unit of analysis is the victim, judges have emphasised that they work and assess cases. ${ }^{109}$ For them, therefore, the unit through which compensation is determined is a case, rather than the victim. In this regard, the study's multivariate regression analysis is complemented by a multilevel analysis in order to control for the variation between cases and also within cases. ${ }^{110}$ In cases with multiple victims, such analysis allows me to determine whether the variables connected to the victim and which appear statistically significant are in fact relevant for the determination of damages or not. As the reader will see, some results from the regular linear regression are dismissed because they give contrasting results to the multilevel analysis.

The data is tested in several stages, in order to test to what extent the variables associated with victim and the state affect the quantum. In the first model, I focus on variables related exclusively to the victim. In this regard, the model analyses how much of the non-pecuniary satisfaction award can be explained by variables related to the individual applicant. The second model looks at the state and its conduct. In this context, I look at who the state is and whether they are a systemic violator. Then, I look at how their conduct has been qualified by the Court (and therefore how serious the violation is). In addition to these two main models, I also investigate to what extent the award of damages is determined by the simple act of making a claim for damages. This is done in the preliminary model, since the rules of the Court require applicants to 'make a specific claim' for just satisfaction. Without such a claim, 'Court considers that there is no call to award him any sum on that account.' ${ }^{111}$ Finally, I join the three models to show how much variability in the data can be explained by putting all three models together. In all three articles, the preliminary model (whether a claim was made) and the last model are the best fit.

The list of variables analysed is contained in the Annex, as well as a description of how they fit into the four models. The results of the regression analysis for each of the three Articles are provided in the annex. ${ }^{12}$

\section{A. The Preliminary Model - Making a claim}

Under Rule 60 of the Rules of Court any claim for just satisfaction must be itemised and submitted in writing together with the relevant supporting documents or vouchers, 'failing which the Chamber may reject the claim in whole or in part'. This statement suggests that the inherent purpose of compensation is to 'place ... [the injured party] in the position in which he or she

\footnotetext{
107 Oleksy v. Poland, App. No. 1379/06 (Eur. Ct. H.R. July 16, 2009); Burden v. UK, App. No. 13378/05 (Eur. Ct. H.R. April 29, 2008), para. 33.

108 Scordino v Italy (no.1), app.no. 36813/97, Grand Chamber, 29 March 2006.

${ }^{109}$ Interview with ECtHR Judge 24, March 2018.

${ }^{110}$ Dhami, M. K, \& Belton, I. (2016). Statistical analyses of court decisions: An example of multilevel models of sentencing. Law and Method. DOI: 10.5553/REM/.000019, https://pdfs.semanticscholar.org/1276/633f2001d4a98dba9e51eb517489d54fd8b2.pdf.

${ }^{111}$ Practice Directions (n 51); Drozd v Ukraine, app.no. 12174/03, 30 July 2009, para 75; Gharibachvili v. Georgia, app.no. 11830/03, 29 july 2008.

${ }_{112}$ Multilevel results can be provided upon request. The Asterix in the list of variables means: In Article 2, where the majority of the victims are deceased, the applicant is claiming compensation for their own pain and suffering due to the deprivation of life of a relative (ie victim). In this regard, in the context of Article 2, I use an additional model to determine the role of the applicant (who makes the claim). This is in addition to the model which investigates the role of the victim (relative who is deceased).
} 
would have been had the violation found not taken place.' 113 'Reparations should not make the victims or their successors either richer or poorer. ${ }^{114}$ In this regard, if a claimant makes no claim for damages, they are considered not to have suffered loss and therefore no compensation should ensue in such situations. ${ }^{115}$

The empirical results reveal that whether a victim makes a claim is significantly determinative of whether they are likely to get the compensation in Article 2, 3, and 5 claims. ${ }^{116}$ The majority of those who made no claim also received no compensation $(98,85$ and $97 \%$ for the three articles respectively). Yet, as scholars note, the European Court has awarded compensation in certain cases in which the applicant has not asked for compensation or in which they failed to submit the claim within the required time limits. ${ }^{117}$ In Fedorov case, for example, the Court held

The applicant did not submit [a claim] within the required time-limits. In such circumstances the Court would usually make no award. In the present case, however, the Court has found a violation of the applicant's right not to be subjected to inhuman and degrading treatment. Since this right is of an absolute nature, the Court finds it possible to award the applicant 10,000 euros (EUR) by way of non-pecuniary damage. ${ }^{118}$

Most of the cases in which an award is made regardless of the absence of the victim's claim related to inhuman and degrading treatment or inhuman treatment. ${ }^{119}$ In cases in which ill treatment was not qualified as inhuman, the Court ruled that although it would usually make no award without a claim. However, the 'absolute nature of the right' and 'fundamental character' of Article 3 required it to award non-pecuniary damages. ${ }^{120}$

Cases in which the Court awards damages without a victim's request are exceedingly rare. ${ }^{121}$ The Court acknowledges such exceptional treatment in the use of its phrasing. On one side, it argues that 'the applicant must have suffered' 122 or that 'a mere finding of a violation' cannot compensate the 'distress and frustration resulting from the procedural violation of Article $3 .{ }^{123}$ The absoluteness of the provision of Article 3 appears to have a special bearing on the Court's consideration. Both Articles 2 and 5, which are not absolute lead to fewer awards

\footnotetext{
113 Practice Directions, ibid, para 10.

${ }^{114}$ Case of Ituango Massacres v. Colombia, Preliminary Objections, Merits, Reparations and Costs, Judgment of 1 July 2006, Inter-American Court of Human Rights, [348].

115 Pinto and van Aaken ( $\mathrm{n} 87$ ) on cases in which no claim is made.

${ }^{116}$ An initial look at the Article 3 data shows that out of 1128 victims, 1027 made a specific claim for damages setting out the amounts requested, 37 victims left the determination of the level of award to the Court (3\%), whilst 64 of applicants did not make a claim for damages or were out of time (5.6\%). Out of the 64 victims who made no claim, 54 victims were not awarded any non-pecuniary damage. In relation to Articles 2 and 5, the picture is similar. 108 Article 5 victims out of 1247 made no request for non-pecuniary damages and 105 received none. And in relation to Article 2, 72 applicants out of 791 made no claim and out of those, 71 received no damages. This is confirmed in the results of the regression analysis of all three models. The act of making a claim is able to explain between $40-68 \%$ of variability in the data.

${ }^{117} \mathrm{P}$ Tavernier 'La contribution de la jurisprudence de la CEDH relative au droit de la responsabilite international en matiere de reparation - Une remise en cause necessarie’ RTDH 72 (2007) 958; Ichim (n 12).

${ }^{118}$ Vladimir Fedorov, Judgment of 30 July 2009; exactly the same phrasing in Nadrosov v Russia 31 July 2008; Borodin v Russia Judgment of 6 November 2012.

${ }^{119}$ Igor Ivanov v Russia, Judgment 7 June 2007, [50].

${ }^{120}$ Chember v Russia, Kats and others v Ukraine. Also Igor Ivanov v. Russia, no. 34000/02, § 50, 7 June 2007 , and Mayzit v. Russia, no. 63378/00, $\S \S 87-88,20$ January 2005), plus any tax that may be chargeable.

${ }^{121}$ In the dataset, such cases were only 10 , out of 64 in which no claim was made; i.e. less than $1 \%$ of the whole dataset of Article 3 violations. These awards appear to have been made only once a year, though perhaps this will change in light of the Nagmetov decision.

${ }^{122}$ A.N. v Ukraine, app.no. 13837/09, judgment of 29 January 2015.

${ }^{123}$ Korobov v Estonia, app. no. 10195/08, judgment of 28 March 2013.
} 
for victims who made no request. On the other side, the Court also seeks a pragmatic explanation for its award. It argues that the different treatment is necessary because the applicant was unrepresented and that given the circumstances it was 'exceptionally possible' 124 to award the applicant non-pecuniary damage and that such a different approach was 'warrant[ed]'. ${ }^{125}$

\section{B. The Victim Model: The Victim and Levels of Suffering}

For those victims, who do request some compensation for their suffering, the Court would be expected to be seeking to address the victim's harm or loss. In this regard, one would expect just satisfaction to be adjusted according to variables related to the victim. On one side, the Court could take into account the loss reported by the victim, on the other, it could adjust the award depending on the particular circumstances of the individual victim. In this section, I seek to establish first whether the victim's assessment of loss or harm potentially affects the final award. In addition, I look at whether the awards are adapted to each individual's circumstances: the analysis considers the impact of applicant's age, gender, their vulnerability (health, race/nationality, gender, other) on quantum as well as serious consequences suffered by the victim. In the context of Articles 2 and 5, I also consider whether the individual's contribution to the situation may affect the damage amount.

\section{Assessing the harm and reporting one's loss}

The European Court of Human Rights acknowledges that '[i]t is in the nature of non-pecuniary damage that it does not lend itself to precise calculation. ${ }^{126}$ In this context, the loss will be subjective to the applicant and intangible, meaning no real proof can be adduced. ${ }^{127} \mathrm{~A}$ victim may experience 'specific feelings of humiliation and degradation' 128 or 'a loss of human dignity" 129 but those who suffer may "not always have an altogether clear-sighted appreciation of their condition.' ${ }^{130}$ In this context, individuals may feel that 'no amount of money would be capable of compensating the harm suffered by them' ${ }^{131}$ and so may request only symbolic compensation. In the same vein, a victim may feel that values protected under the Convention may be 'incommensurable" 132 and may be not willing to accept 'anything less than an infinite sum of money'. ${ }^{133}$

Given these acknowledged difficulties in the determination of non-pecuniary damages, the Court has adopted and regularly employs a 'series of detailed tables setting out a method of calculation of non-pecuniary damage in respect of each article of the Convention. ${ }^{134}$ As a

\footnotetext{
${ }^{124}$ Kats v Ukraine, app.no. 29971/04, judgment of 18 December 2008.

${ }^{125}$ X v. Croatia, app. no. 11223/04, judgment of 17 July 2008; Mayzit v. Russia, app.no. 63378/00, Judgment of 20 January 2005).

${ }^{126}$ Practice Directions (n 51), para 14.

127 This subjective element of non-pecuniary damage has been criticised by judges. In Kasperovičius, Judge Jočiene questioned the issue that the just satisfaction claim of the applicant was 'not supported by any medical evidence which might provide proof of the adverse consequence caused to the applicant, such as distress and/or frustration.' Instead, he noted that '[t]he claim is based on the applicant's personal assessment, which cannot be considered reasonable in the particular circumstances of this case.' Application 54872/08, 20 November 2012.

${ }^{128}$ B. Phillips, 'The Case for Corporal Punishment in the United Kingdom. Beaten into Submission in Europe?' (1994) 43 ICLQ 153.

${ }^{129}$ J Vorhaus 'On Degradation. Part One: Article 3 of the European Convention on Human Rights' (2002) 31 Common Law World Review 374, 380.

130 Ibid.

${ }^{131}$ Lorse v Netherlands, app.no. 52750/99, 4 February 2003; Shismanov v Bulgaria, app.no. 37449/02, 8 January 2009.

132 Shelton (n 16) 29.

${ }^{133}$ R Posner Economic Analysis of the Law (Little Brown and Co, 1977) s 6.12, 197.

${ }^{134}$ Harris (n 9) 155-6.
} 
consequence, the awards are standardized and in principle not influenced by the level of award requested. The presence of tables effectively removes the most frequent bias in damage determination - the so-called anchoring effect, when those victims who assess their harm and suffering as higher also receive higher awards. This cognitive bias is regularly identifiable in tort and in wrongful death damage awards, when judges or juries rely too heavily on the damage claims made by the plaintiff. ${ }^{135}$ Yet, before the European Court of Human Rights, the empirical analysis shows that there is no correlation between the amount claimed and the award provided. ${ }^{136}$ In effect, by adopting detailed tables the Court has removed the danger of anchoring and the request by the victim has no influence on the award received.

Of course, this is not the complete picture. For example, when individuals who feel that 'no amount of money would be capable of compensate the harm suffered by them', ${ }^{137}$ request only symbolic compensation, they usually receive the full amount requested. In Lorse, for example, the victim asked for 1000 Dutch guilders as just satisfaction for detention in a maximum-security prison, which constituted inhuman and degrading treatment. The Court awarded the applicant the full amount in Euros, the least it has ever awarded for inhuman and degrading treatment. Following the tables of the Court, the victim would have likely received a higher amount. ${ }^{138}$

In addition, it is important to note that the requests for compensation often mirror the Court's previous case-law. The Practice Directions explicitly invite applicants to specify a sum which in their view would be equitable. In practice, lawyers set an 'equitable sum' by looking at awards made in previous similar cases against the same respondent state. They then make a compensation request following that case law. If Court's previous awards are taken as a guide for an equitable/just claim, ${ }^{139}$ the requests made are not independent of previous awards and will of course correlate with the amounts awarded. ${ }^{140}$ Some NGOs use the practice of mirroring to push damage amounts higher. By looking at the practice and citing other cases, they draw distinctions with previous practice and strategically argue for an increase in damage awards. ${ }^{141}$ To the extent that victims and their lawyers follow previous practice, the Court may be willing to agree with the victim's subjective assessment of harm and adjust the damages slightly higher.

As another proof of the existence of tables, the statistics make clear that victims who leave the determination of the award to the Court's discretion do not receive significantly different satisfaction than victims who ask for a specific monetary sum. ${ }^{142}$ This result is perhaps

\footnotetext{
135 Yun-Chien Chang; Theodore Eisenberg; Han-Wei Ho; Martin T. Wells, Pain and Suffering Damages in Wrongful Death Cases: An Empirical Study, 12 J. Empirical Legal Stud. 128 (2015), Guthrie, Chris, Jeffrey J. Rachlinski, \& Andrew J. Wistrich (2000) 'Inside the Judicial Mind,' 86 Cornell Law Rev. 777; Campbell, John, Bernard Chao, Christopher Robertson, \& David Yokum (2014) "Countering the Plaintiff's Anchor: Jury Simulation to Evaluate Damages Arguments," 101 Iowa Law Review 543 (2016).

136 This appears to be affirmed by a lack of correlation between the claimed award and the award received (corr. -0076 , not significant) and by the results of the regression analysis (see annex).

${ }^{137}$ Lorse $v$ Netherlands (n 118).

${ }^{138}$ Normally, just satisfaction for inhuman and degrading treatment starts with 1000 Euros and 5000 Euros is the most frequently awarded sum.

${ }^{139}$ Looking at the case-law, the most that has been awarded as just satisfaction for Article 3 violation (in the 13 years under investigation) is 105,000 Euros in Kopylov $v$ Russia case. 989 out of 1128 Article 3 victims made a claim lower than that amount.

140 corr. 258. Correlation is significant at 0.01 level. Out of 1128 victims, 87\% (982) asked for less than Euros 105,000. Similar results are confirmed in relation to Article 2 (corr. 0.153*) and (corr. 0.174*).

${ }^{141}$ European Human Rights Advocacy Centre, for example, has through its work secured award increases for disappearances from 50 to 60000 Euros.

142 Anova Sig (.273).
} 
most relevant to practitioners: as long as a claim for non-pecuniary damages is made, the individual should get compensation regardless of whether they specify the amount or leave the assessment to the Court. In fact, the discovery might encourage practitioners to not set damage amounts in case they may inadvertently cap compensation at a lower amount than the Court may be willing to award. Indeed, some NGOs appear to be already aware of this practice and have strategically left the quantification of damages to the Court. ${ }^{143}$

\section{An individualised award}

The purported focus of the Court on the victim is tested further through the principle of equity, which according to the Court 'involves flexibility and an objective consideration of what is just, fair and reasonable in all the circumstances of the case, including not only the position of the applicant but the overall context in which the breach occurred. ${ }^{144}$ The equitable principle implies that the Court treats victims in similar situations similarly and those in different situations differently. Whilst the regression analysis shows that there is no variation in damages due to victim's gender or age, I explore the results in relation to the other variables below.

\section{Victim's vulnerability and impact of the violation}

In his book on Just satisfaction under the ECHR, Ichim argues that for victims that are particularly vulnerable, 'the award will go towards the maximum limit. ${ }^{145} \mathrm{He}$ also cites two cases (one under Article 2 and one under Article 3) in which victim's vulnerability was taken into account in the award of damages. ${ }^{146} \mathrm{I}$ decided to test this claim in our dataset. Out of 1128 Article 3 applicants, 225 victims were coded as vulnerable. Following the case-law, we defined 'vulnerability' as including applicants that were particularly young or elderly, ${ }^{147}$ those that suffered a serious or chronic medical condition ${ }^{148}$ or were vulnerable because of their gender, ${ }^{149}$ as well as members of minorities. ${ }^{150}$ When the Court therefore in its judgment found an applicant vulnerable due to their age, gender or other, we coded the applicant as vulnerable. ${ }^{151}$ The T-test analysis showed that there was no significant difference in award between cases in which applicants were qualified as vulnerable and cases in which no vulnerability was reported. ${ }^{152}$ In the regression analysis, the victim model shows a negative, though not significant impact of vulnerability on damages. The results are similar in the context of Article 2, where 371 out of

\footnotetext{
${ }^{143}$ Open Society intervention argued in favour of this tactic at EHRAC Symposium. Though note that an NGO may also seek to actively change the practice of the Court and encourage it to improve compensation.

144 Varnava (n 48); Al-Skeini and others v. United Kingdom, app.no. 55721/07, 7 July 2011.

${ }^{145}$ Ichim (n 12) para 6.5.3.

146 Nencheva and Others v. Bulgaria no. 48609/06, 18 June 2013; Wenerski v. Poland (no. 2) no. 38719/09, 24 July 2012.

147 Nieciecki v Greece, app.no. 11677/11, 4 December 2012; Sarigiannis v Italy, app.no. 14569/05, 5 April 2011; Salmanoglu v Turkey, app.no. 15828/03, 17 March 2009, etc.

${ }_{148}$ Micrea Dumitrescu v Romania (n 75); Kovalchuk v Ukraine, app.no. 21958/05, 4 November 2010 (health, wheelchair).

149 This is particularly the case in domestic violence cases. Valiuliene v Lithuania, app.no. 33234/07, 26 March 2013, or in prison where a male applicant was ordered ordered to strip naked in the presence of a female prison officer, Wiktorko v Poland, app.no. 14612/02, 31 March 2009.

${ }^{150}$ Roma minority in particular: Koky and others $v$ Slovakia, app.no. 13624/03, 12 June 2012; Dzeladinov v Macedonia, app.no. 13252/02, 10 April 2008.

${ }^{151}$ It should be noted, however, that although all persons in custody under Article 3 are considered 'vulnerable' because they are under the control of state authorities, we did not code these as vulnerable unless the Court found the applicant was in a particularly difficult position because of his personal circumstances. We therefore sought to isolate the impact of applicant's personal circumstances from the general position in which detainees find themselves. D.F. v Latvia, app.no. 11160/07, 29 October 2013; Lautaru v Romania, app.no. 13099/04, 18 October 2011.

${ }^{152}$ Even taking account of all mentions of vulnerability (including those that refer to general applicant vulnerability), there is still no correlation between vulnerable victims and the award provided.
} 
791 victims (not applicants) are labelled as vulnerable. ${ }^{153}$ In Article 5, the victim's vulnerability appears to have no impact on the award.

Scholars insist that in addition to the victim's vulnerability, one of the elements that affects the level of awards is also the injury that the applicant may have suffered as a consequence of state conduct. ${ }^{154}$ The Inter-American Court, for example, appears to differentiate between victims on the basis of whether they had suffered complete permanent or permanent but partial disability, a permanent injury or other injury. ${ }^{155}$ The ECtHR argues that it 'must ... take into account the serious consequences the treatment had on the applicant' when evaluating whether the treatment 'reached the minimum level of severity required for application of Article 3 of the Convention. ${ }^{156}$ Yet, it is unclear whether the Court takes the injury suffered by the victim into account when determining damages.

In his opinion in Kasperovičius, ${ }^{157}$ Judge Jočiene appears to suggest that the injury should play a role in the setting of quantum. The case concerned a 7-day detention in poor conditions of a 44 year-old healthy man. The detention had 'no negative impact ... on the applicant's physical health' and based on applicant's personal circumstances, the dissenting judge argued that 'in determining the amount of the award, the above-mentioned [element] should have been taken into account and therefore the award for non-pecuniary damage should have been significantly reduced in this case.' ${ }^{158}$

The regression analysis in the victim model shows that the impact of the violation on the victim will not influence the award. If an applicant develops a chronic condition as a result of conditions in prison, or if they are severely and permanently injured as a result of Article 3 state conduct, ${ }^{159}$ the award will not differ considerably than in the case where the victim suffers no long-term consequences. The same holds in situations in which the person dies as a result of the violation and a relative makes the application on their behalf. The results are consistent across the different models. ${ }^{160}$

The irrelevance of both vulnerability and the impact the violation had on the individual on damage awards is striking. It is possible that the Court takes the applicant's vulnerability (age, gender, disability or health condition, ethnicity and other) into account only when establishing a violation and that, as a consequence, vulnerable individuals are more likely to have suffered a human rights breaches than other individuals. ${ }^{161}$ In a similar manner, this result could mean that the 'serious consequences of treatment' are considered at the level of determining the type of ill-treatment only. Yet, once this ill-treatment has been qualified as torture, inhuman or degrading treatment, the impact of injury on damages is no longer palpable. It appears therefore that vulnerability or serious consequences may form part and parcel of the

\footnotetext{
${ }^{153}$ In the regular linear regression analysis, the impact of the vulnerability is significant and negative, and victims that have a health problem or have been singled out as vulnerable because of their nationality, race or gender, appear to receive less than other applicants. In the multilevel model, this negative impact on quantum is lost.

${ }^{154}$ O. Dörr, 'Entschädigung und Schadensersatz', in: R. Grote /T. Marauhn, Konkordanzkommentar zum europäischen und deutschen Grundrechtsschutz, 2nd ed. 2013, 2148.

155 Castro-Castro Prison v Peru, (Merits, Reparations and Costs), Int-Am Ct HR, Judgment of 25 November 2006, Series C No.160, paras. 421, 424-5, 432-3.

156 Bureš v Czech Republic, app.no. 37679/08, 18 October 2012.

${ }^{157}$ Kasperovičius v Lithuania, app.no. 54872/08, 20 November 2012.

158 ibid.

159 Sacilik (n 160), case of amputation; Yermolenko v Ukraine, app.no. 49218/10, 15 November 2012.

160 There is a slight negative impact for individuals who have only suffered risk of death but not actually experienced further trauma but the results are negligible due to a low number of cases within the four categories.

${ }^{161}$ Ireland $v U K$ (n 83) [162]: 'The assessment of this minimum is, in the nature of things, relative; it depends on all the circumstances of the case, such as the nature and context of the treatment, its duration, its physical or mental effects and, in some instances, the sex, age and state of health of the victim...'
} 
violation and that the impact on the applicant is not significantly relevant to the setting of quantum. ${ }^{162}$ Once a breach has been established, personal circumstances of the victim appear to have no bearing on the award.

\section{Group vs individual cases}

The Court allows applicants whose complaints are based on the same or similar facts or applicants who find themselves in similar circumstances (e.g. in the same prison) to make the application together. Under Article 3, these mass violations cases arise particularly when detention in poor conditions ${ }^{163}$ is alleged or when breach of the Convention has arisen as a consequence of police violence in the context of protests ${ }^{164}$ or mass detention. ${ }^{165}$ In Article 2 cases, they concern mass disappearances or hostage crises, where many individuals died at the same time. ${ }^{166}$ Such cases often reveal a consistent or systemic problem and touch upon issues that have arisen from the same event.

In principle, appearing in a group with other claimants rather than on their own should not affect the level of award received. Yet, according to the textbooks on the topic, there is anecdotal evidence to suggest that in multiple applicant cases, compensation to each victim is lower than if they had appeared in a single-applicant claim. ${ }^{167}$ The results of the regular regression analysis support these statements: the group has a negative impact on the award received by the individual victim. Individuals receive approximately 30 euros less for each applicant in an Article 3 case, 67 euros less for each applicant in an Article 5 case, and 318 euros less per applicant in an Article 2 case. ${ }^{168}$

The reasons for this different treatment could be evidentiary. On one side, mass violations 'are often characterised by the fact that victims have limited evidence to show that they suffered a violation.' Although this may appear counter intuitive given the scale of the violation, victims have often lost relevant documents that may prove ownership or identity; they may be traumatised or may have been threatened; considerable time may have passed since the event etc. ${ }^{169}$ All of these elements represent an obstacle to showing the failure on the part of the state to investigate their case. Even more, 'the circumstances of mass violations and the large number of victims frequently make it difficult to compile the required evidence. ${ }^{170}$ For this reason, the Inter-American Court of Human Rights accepts a lower standard of plausibility as proof, ${ }^{171}$ thus easing the burden on applicants. Before the ECtHR, however, the evidentiary difficulties apply 'in equal measure to proving damages'. ${ }^{172}$ As a consequence, groups seeking

\footnotetext{
162 The results especially regarding the impact on the victim should be tested on a bigger sample ( $\mathrm{N}=12$ victims with serious consequences.)

${ }^{163}$ Sakar and others $v$ Turkey, app.no. 38062/08, 20 October 2015; Taggatidis v Greece, app.no. 2889/09, 11 October 2011, etc. The poor conditions cases regularly concern the same prisons - Jilava, Rahova, Galati prisons in Romania; Ioannina prison in Greece, and special detention prisons in Russia IZ.

${ }^{164}$ Habimi v Serbia, app.no. 19072/08, 3 June 2014.

165 Sacilik (n 160); Alecu v Romania, app.no 56838/08, 27 January 2015.

${ }^{166}$ Finogenov v Russia, app. no. 18299/03, 20 December 2011.

${ }^{167}$ Harris (n 9) 156; see also explanation in ECtHR, Arvanitaki v. Greece, Appl. no 27278/03, Judgment of 15 February 2008), underlying that group cases are different.

${ }^{168}$ For ease of interpretation, these initial values are produced in a regular regression analysis, where the award is not given in a logarithmic form. All results are significant.

${ }^{169}$ Lutz Oette 'Bringing Justice to Victims? Responses of Regional and International Human Rights Courts and Treaty Bodies to Mass Violations' in C. Ferstman, M. Goetz and A. Stephens Reparations for Victims of Genocide, War Crimes and Crimes Against Humanity (Martinus Nijhoff 2009) 233.

170 Ibid, 227.

${ }^{171}$ H. Holtzmann and E. Kristjansdottir, International Mass Claims Processes (OUP 2007), 210 and ff.

172 Oette (n 149) 233.
} 
to prove state misconduct might struggle proving their case and this might influence compensation.

In other cases, in which appearing in a group might be easier, other factors might influence the reduction in compensation. In cases alleging mass violations like inhuman or degrading treatment due to poor conditions, the task of groups is likely to be easier. The Court in these cases relies heavily on reports provided by the European Committee for the Prevention of Torture, which visits and assesses the state of prisons around Europe. The Court presents the findings of the Committee as well as its recommendations. This reliance on an external expert and fact-finding body reduces the need for applicants themselves to gather evidence about their situation. In this regard, their inconvenience and uncertainty is alleviated. Yet, the Court has underlined that the sole fact of appearing as a group in a 'single set of proceedings with a shared objective ... alleviated the inconvenience and uncertainty experience[d] ... and so meant a reduction in the amount of the award. ${ }^{173}$ Appearing in front of the Court with others, therefore, provided individuals with support and could lead to a decrease in quantum.

Furthermore, it is clear that when victims appear together with others who have suffered similar fate, they are likely to be treated similarly. In this regard, there is clearly a lack of individualisation. Judge de Albuquerque argues that 'the basic compensatory principle is the imperative of individualised compensation, which implies that pre-determined, flat or fixed daily compensation will be inadmissible. ${ }^{\prime 74}$ In particular in respect of claims in which multiple applicants are alleging similar conduct or find themselves affected by the same event, the amount of award must correspond to 'concrete situation of each' applicant. ${ }^{175}$ This requires that the duration and severity of detention conditions be taken into account.

The only contrast that is made between victims in group cases in Article 2 cases is based on the relationship the applicant enjoyed with the victim (with the partner and parents of the victim receiving more in damages than other relatives). The impact is especially strong in cases of financial dependency. ${ }^{176}$ Beyond this, however, 'reparation measures tend to be of a general (and collective) nature.' ${ }^{177}$ By its nature, mass violations shift 'the focus from the identity of the applicant to the nature of the violation.' ${ }^{178}$ Before the Inter-American court of Human Rights, for example, '[t]he principal approach is to award the same amount of compensation to all victims falling within the category, in particular for non-pecuniary damages. ${ }^{179}$ This lack of individualisation can be noticed also before the ECtHR. In Taggatidis, for example, 47 applicants brought a complaint about poor conditions in Ioannina prison. ${ }^{180}$ Some of the prisoners had spent over 11 years in badly ventilated cells and suffered medical problems, whilst others lived there for a few months. For a couple of prisoners, the duration was unknown. Yet, the Court in awarding damages made no distinction between the victims, awarding each one 10,000 Euros. This standardisation of amounts of compensation did not go unnoticed. In $\mathrm{Sa}$ cilik, a case concerning police violence, Judges Popović and Sajó criticised the Court's failure to distinguish between the suffering of the victims:

\footnotetext{
173 Arvanitaki-Roboti v Greece (2008) GC, para 29-32; also KAKAMOUKAS and Others v Greece (No 38311/02).

${ }^{174}$ Mironovas (n 67), separate opinion of Judge Pinto de Albuquerque, [15].

175 Ibid.

${ }^{176}$ See multilevel results for Article 2 in annex.

177 Oette (n 149) 223.

178 Though this is noted in particular in the context of standing, it also explains the Court's treatment of group actions. Oette (n 149) 222.

179 ibid; citing three Inter-American Court cases: Rochela Massacre v Colombia, Case of Montero Aranguren et al (Detention Center of Catia) v Venezuela; and Castro-Castro Prison v Peru.

180 Taggatidis (n 143).
} 
The sums ... awarded take into account neither the gravity of the injuries suffered by each applicant nor the respective periods for which they were unable to work. ... we find it indispensable to consider the amount of suffering inflicted on the applicants when awarding just satisfaction, especially in a situation such as the present one, where the only information available relating to the inhuman and degrading treatment (including, for example, the anxiety and helplessness the prisoners must have felt) concerns the gravity of the injuries. Those who suffered less should be awarded a smaller sum than those who suffered more. ${ }^{181}$

In subsequent cases, the Court appears to have addressed the issue, at least in the context of poor conditions. A year after Taggatidis (and Sacilik), it applied three different amounts in Samaras and Tzamalis ${ }^{182}$ and later in Torregiani, Nikolaos and Lakatos. ${ }^{183}$ The Court awarded three different award amounts depending on the duration of imprisonment in poor conditions. ${ }^{184}$ In turn, awards for poor conditions appear to be correlated with the time spent living in those conditions. ${ }^{185}$

\section{Conclusion}

The results of the regression analysing reveal how little relevance victim variables in fact have on the determination of damages. The victim model explains only between $0-5 \%$ of the variability in the award of just satisfaction. ${ }^{186}$ This is consistent across the different articles. The result is negligible. It suggests that the victim is clearly not at the centre of the Court's analysis. We therefore turn to consider whether the variables associated with the state can better explain the non-pecuniary awards.

\section{The State Model: The Conduct of the State}

There are three aspects in which the state may play a role in the determination of damages: first, through its conduct; secondly, according to the identity of the state and how rich or poor it may be; and finally, how frequent a violator of the respective article the state is. These three variables are analysed in the next sections.

\section{State conduct}

The Convention protects a number of legal interests. Many have argued or wondered to what extent articles of the Convention reveal a hierarchy of rights, ${ }^{187}$ with the right to life and the prohibition of torture protecting the most important ${ }^{188}$ and essential legal interests and other articles then focusing on progressively 'lesser' values such as liberty, procedural justice, and private and family life and property. As Ichim maintains, although 'the Convention avoids categorization of the rights, ... the rights are listed according to their importance even if, again, officially there should be no hierarchy.' 189

\footnotetext{
${ }^{181}$ Sacilik and others v Turkey, app.no. 43044/05, 5 July 2011.

182 Samaras and others $v$ Greece, app.no. 11463/09, 28 February 2012; Tzamalis and others $v$ Greece, app.no.15894/09, 4 December 2012.

${ }^{183}$ Torregiani and others $v$ Italy, app.no. 43517/09, 8 January 2013.

${ }^{184}$ Tzamalis (n 163) and same in Samaras (n 163) 7000, 10000 and 15000.

${ }^{185} \mathrm{~N}=347$ victims in poor conditions, corr. $+.286^{* * *}$. In fact, the subsequent findings of my empirical analysis of Article 6 cases (which will be published in due course) show that in assessing the state's conduct in Article 6 cases (most of which are length of proceedings cases), the court counts the number of years of delay. V. Fikfak 'Quantifying Pain and Suffering in Human Rights Adjudication', forthcoming.

${ }^{186}$ For Article 2, applicant $\mathrm{r} 2=0.079$, victim 0.050; for Article 3, 0.006, for Article 5, 0.021 . Note that the $8 \%$ in Article 2 refers to the applicant and his relationship to the victim and not to the victim. The results for Article 6 , which are not included in this article, similarly confirm the irrelevance of variables related to the victim.

${ }^{187}$ E. De Wet and J. Vidmar, Hierarchy in International Law, The Place of Human Rights (OUP 2012).

188 Ichim (n 12) 128.

${ }^{189}$ Ibid.
} 
When in 2006, a new Just Satisfaction Unit was established within the Court, its aim was to 'adopt a series of detailed tables setting out a method of calculation of non-pecuniary damage in respect of each article of the Convention'. The Court was driven by a concern 'not only to ensure consistency of awards as between the Court's five Sections, but also to ensure consistency as between the different articles of the Convention that have been violated.' As Harris and others argue, this was done since 'it had been observed that on occasions the awards for very serious breaches (loss of life or torture) were lower than awards for lesser breaches (loss of liberty or freedom of expression). ${ }^{190}$ In its study of 2006 case law, the Max Planck group assessed what value (in terms of compensation) was assigned to different legal interests as protected by the articles of the Convention. They found that the most intense type of violation - the right to life and the prohibition of torture drew the most generous compensation levels. ${ }^{191}$ In this regard, the hierarchy of the articles of the Convention was reflected in the compensation awarded. ${ }^{192}$

In my model, I study the gravity of the violation not as a mirror of the hierarchy of the different articles of the Convention, but rather by focusing on different types of state conduct which can lead to the violation of the same Convention article. Article 3, for example, prohibits torture, inhuman and degrading treatment. At first sight, one would expect that the Court distinguishes between these three specific conducts of the state. The Court has said that, 'it was the intention that the Convention with its distinction between torture and inhuman treatment should by the first of these terms attach a special stigma to deliberate inhuman treatment causing very serious and cruel suffering.' 193

It is clear from the results of the dataset that in awarding compensation for different types of violations, the Court appears to be singling out torture in Article 3 from other behaviour. ${ }^{194}$ A sole act of torture generates about 20,000 Euros, compared to acts of inhuman treatment generating about 1900 Euros, degrading treatment or general ill-treatment under Article 3 about 3000 Euros and inhuman and degrading treatment at about 5600 Euros. The gap between torture and other type of state conduct under Article 3 is therefore immense. This appears to be consistent with the special stigma attached to torture.

Similarly, Article 5 is divided into different paragraphs. Whilst the first paragraph sets out the general right to liberty and thus prohibits arbitrary deprivation of liberty, the subsequent paragraphs set out rights of those who have been detained in order to ensure that this detention is lawful. An act of arbitrary detention will generate the best compensation (around $3000 \mathrm{Eu}-$ ros) in the context of the protection of liberty, whilst Article 5-3 which protects persons pending trial on criminal charges will lead to considerably lesser damages (eg approximately $90 \mathrm{Eu}-$ ros). ${ }^{195}$

It is clear therefore that the specific state conduct importantly influences the compensation awarded and that one type of behaviour is singled out. ${ }^{196}$ In addition, it is hypothesised (by Ichim) that procedural limbs of both Articles 2 and 3 do not generate as much compensation as substantive violations (eg degrading treatment). ${ }^{197}$ In this context, we would expect that the

\footnotetext{
${ }^{190}$ Harris (n 9) 155-6, emphasis added. Note that there is no footnote to reveal in which cases this happened.

${ }^{191}$ Altwicker (n 17) 32.

192 The study did find some discrepancies from the traditional hierarchy, eg it found that liberty cases (Article 5) generated less compensation than Article 6 cases (procedural justice). Ibid.

${ }^{193}$ Ireland v UK 18 January 1978, Series A No 25 (1979-80) 2 EHRR 25, [167].

${ }^{194}$ For Article 2 the results are inconclusive: the logarithmic regression puts disappearances on top, whilst the multilevel regression puts excessive force.

195 The result is significant in relation to Article 5-1 violation, but not in relation to Article 5-3.

${ }^{196}$ Most of the conduct by the state is statistically significant.

${ }^{197}$ Ichim (n 12) 129.
} 
failure to investigate an act of inhuman and/or degrading treatment or the failure to prevent a violation (as part of the positive obligation) would lead to a lesser amount of compensation than the act itself. The results suggest that the approach of the Court is not entirely as expected: in Article 3, the failure to investigate costs the state about 4000 Euros, with both inhuman treatment and degrading treatment generating less in compensation. ${ }^{198}$ These results are surprising - potentially suggesting that in certain respects the Court is more concerned about the process and how authorities respond to a case of ill-treatment than the ill-treatment itself. ${ }^{199}$ Positive obligations therefore appear to be more important for quantification of damages.

\section{Adjusting damages to the GDP of the country}

The Court insists that the awards are adjusted depending 'on the overall context in which the breach occurred', ${ }^{200}$ i.e. the 'local economic circumstances'. ${ }^{201}$ It is argued that the Court distinguishes between 'victims in accordance with the level of economic development in the respondent state.' ${ }^{202}$ For example, the Court held that the 'basic award' can be reduced 'on the basis of the standard of living in the country concerned. ${ }^{203}$ Ichim insists that the decision to adapt the damages is not discriminatory since: 'it would make little sense to grant similar amounts for the same violation regardless of whether the applicant lives in a richer or poorer country ... because the value of the money is different and does indeed depend on local economic development and purchasing power.' The sum therefore has to be adapted so that it is commensurate with the standard of living and ensures equivalent purchasing power in all countries. $^{204}$

It is interesting to test these statements in the dataset. The analysis reveals that GDP is indeed positively correlated with the level of the award (corr. 212**). ${ }^{205}$ At first sight, therefore, countries who are richer will pay more for the same type of violation than countries with a smaller GDP. The regression analysis confirms this by showing that 'old countries' - coded on the basis of when they joined the COE and with a considerably higher GDP than the new countries - pay on average 5277 Euros more than new countries and even more than Turkey. ${ }^{206}$ Similar results arise in the context of Articles 2 and 5, where the country variable has a significant impact on the awards given. ${ }^{207}$

However, when the seriousness of violation is taken into account and the level of award is measured against the GDP, what becomes clear is that compensation is not always adjusted to ensure equivalent purchasing power. In particular, degrading treatment and general ill-treatment under Article 3 receives the same satisfaction regardless of the country's GDP. In fact, in the case of general Article 3 violations, the amounts appear to slightly decrease the higher the

\footnotetext{
${ }^{198}$ In Article 2, the substantive violations lead to more compensation than procedural.

199 This is consistent with the statement by Harris that procedural violations may generate better compensation than acts of torture and with Max Planck findings comparing Article 6 to Article 5 awards. It is also consistent with a more general focus of the Court on the procedural limbs of articles 2 and 3, eg identifying specific requirements of effective investigation, etc: J. Kukavica et al, 'Strasbourg's U-turn on Independence as Part of an Effective Investigation under Article 2', (2015) 74(3) Cambridge Law Journal 415-419.

200 Al-Skeini n 126), para 182.

${ }^{201}$ Basarba OOD v Bulgaria, app.no.77660/01, 20 January 2011 [26]. Also in Practice Directions (n 51) [2].

202 Ichim (n 12) 47.

${ }^{203}$ Apicella v Italy, app.no. 64890/01, 29 March 2006. Note that this was an Article 6 cases in which the Court has the most structured approach.

${ }^{204}$ Ichim (n 12) 160. This is consistent with the Court's assertions in Mironovas (n 67).

${ }^{205}$ GDP is coded for the country in the specific year in which decision was rendered.

206 The coding mirrors the coding adopted by the Max Planck Study, Altwicker (n 17), see annex.

207 The impact of the country variable is significant also in the context of Article 6. Only in Article 5 cases does Turkey pay more than rich countries, though this may be due to the data (with the majority of cases coming from Turkey and only $15 \%$ from old countries).
} 
GDP raises. This picture can be contrasted with the awards for procedural violations and torture, both of which increase with the GDP. The rise of awards for torture is particularly striking, with quantum doubling from 20,000 for countries with $\$ 4$ billion GDP to 40,000 for countries with $\$ 4$ trillion GDP.

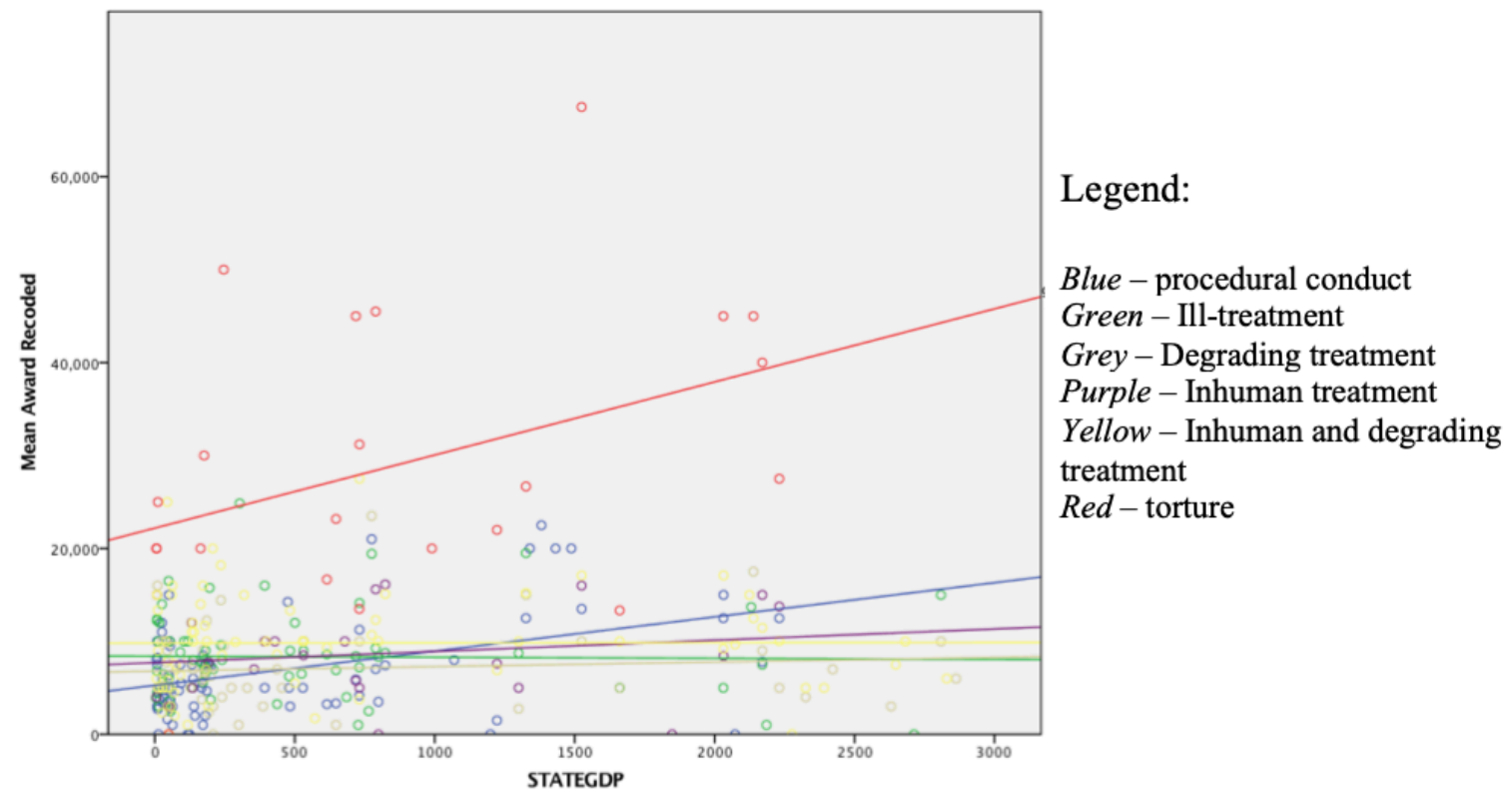

This graph would therefore suggest that the claim that 'local economic circumstances' are taken into account and awards are adjusted to ensure equal purchasing power might not always hold or might not have such as influence as to be statistically significant, at least not for all types of conduct within a Convention article. Instead, the GDP adjustment appears to be used to maximise the punishing effect of torture in rich countries but when it comes to poor conditions, it appears compensation will remain pretty much similar across the different jurisdictions.

\section{Dissuading systemic violators?}

If the Court is seeking to achieve deterrence through just satisfaction awards, then the level of the award will have to be such that state actors are deterred and persuaded that a repetition or continuation of breach is not economically viable. As Shelton argue, whilst retribution focuses on the wrongdoer and on preventing repetition of his action, a broader deterrent effort may seek to influence the behaviour of all potential actors (not just the future conduct of a particular perpetrator). Damages may therefore seek to encourage rational actors to weigh the costs of transgression against the anticipated benefits. In the international context, however, these deterrence goals, become trickier to achieve, because the defendant is 'the state', which has resources far beyond those of an individual perpetrator and can pay compensation from the public treasury. If damages are to pursue a deterrent aim, if they are to act as 'potent restraints' against repetition of violations, then the 'level of the award or the nature of remedy must be such that state actors are deterred and not permitted to purchase an option to continue violating human rights. ${ }^{208}$ In this regard, punitive/aggravated damages will be key. ${ }^{209}$

\footnotetext{
208 Shelton (n 16) 14.

${ }^{209}$ Though in some areas there is little correlation between severity of punishment and reduced incidence of wrongdoing. Nigel Biggar, Burying the Past-Making Peace and Doing Justice after Civil Conflict (Georgetown University Press, 2003) 69.
} 
The systemic variable counts the number of cases of Article 2, 3, or 5 violation appears in my cohort (covering 13 years of caselaw). ${ }^{210}$ This variable produces some of the most interesting results. It first shows that in the context of Articles 2 and 3, there is a slight positive influence on quantum. The more a country violates Article 2 and 3, the more it pays for damages. In Article 2 cases, the state pays approximately 183 Euros more for each additional case, whilst in Article 3 case, the state pays between 21-27 Euros more for each additional case that appears in the cohort. These results are significant, though amounts are negligible and can hardly be called punitive. Even more interesting are results in respect of Article 5, where states pay on average 10-15 Euros less for every additional case of Article 5. This implies that the more a country violates Article 5, the less it pays. I have argued elsewhere ${ }^{211}$ that the same pattern of 'price reduction' can be noticed in the Burmych $v$ Ukraine case, where in a series of decisions relating to the non-enforcement of judgments of Ukrainian courts (ie violations of Article 6), the ECtHR reduced compensation for individuals waiting for enforcement from the initial $€ 5,000$ for non-pecuniary damage in 1999 to $€ 1,000$ in 2015. From 1999 to 2015, the 'price' for non-enforcement of domestic judicial decisions had therefore fallen from $€ 5,000$ to 20 per cent of this amount. ${ }^{212}$

At first sight, these results are surprising. A human rights court is potentially allowing states to pay less the more they violate human rights norms. ${ }^{213}$ When asked about these results, judges admit that sometimes concerns about compliance may affect the setting of damages. ${ }^{214}$ In this regard, if a country has many repetitive cases arising from a systemic violation, the Court may be inclined to lower the award to provide 'at least something' to victims. ${ }^{215}$ The lower the damages are, the reasoning goes, the more likely the state is to pay and the more likely the Court is to rid itself of the large number of (repetitive) cases. Yet, according to behavioural economists the decision to adjust or effectively lower damages to facilitate states' compliance has no deterrent effect and, may potentially be leading to the potential collapse of the system. ${ }^{216}$ In 2017, in Burmych v. Ukraine, when the issue of non-enforcement of domestic judgments arose again before the Court, the Grand Chamber effectively gave up on trying to incentivize Ukraine to comply with its judgments. The Court dismissed all of its remaining 12,148 non-enforcement cases as well as any future cases ${ }^{217}$ and forwarded them to the Department of Execution at the Council of Europe. The Court's argument was that it had done everything it could, and now it was up to the Department of Execution to find a solution for the implementation of its judgments. ${ }^{218}$ The monies still remain unpaid.

\footnotetext{
${ }^{210}$ I chose this variable because it is easiest (ie can be counted). It produces comparable results as if we coded the term 'systemic' in the judgments or used the existing CIRI data, Cingranelli, David L., David L. Richards, and K. Chad Clay. 2014. "The CIRI Human Rights Dataset." http://www.humanrightsdata.com. Version 2014.04.14.

${ }^{211}$ Fikfak (n 1) EJIL article.

${ }^{212}$ This result is confirmed in the larger dataset including more than 1000 cases of Article 6 claims. Results will be published in a forthcoming article.

${ }^{213}$ When I saw the initial results, I was hesitant to assume that the Court was actively reducing the quantum for frequent violators (distinguishing between correlation and causality). I therefore sought to verify the results in interviews with judges.

${ }^{214}$ Interviews with ECtHR Judge 27 and 30, February 2018.

215 ibid.

${ }^{216}$ Louis Vischer, 'Economic analysis of punitive damages' in Koziol H., Wilcox V. (eds), Punitive Damages: Common Law and Civil Law Perspectives, Tort and Insurance Law book series (25), Springer Vienna, 2009 on how damages should be unpredictable, high and individualized in order to have deterrent effect.

${ }^{217}$ Burmych and Others v. Ukraine, Appl. no. 46852/13, Judgment of 12 October 2017, para 6; Dissenting Opinions of Judges Yudkivska, Sajó, Bianku, Karakas, De Gaetano, Laffranque and Motoc on pro futuro aspect of the judgment.

${ }_{218}$ This conclusion was challenged by very strong dissents. Burmych and Others $v$. Ukraine, ibid, paras 13, 19, Dissenting Opinions of Judges Yudkivska, Sajó, Bianku, Karakas, De Gaetano, Laffranque and Motoc.
} 
This focus on compliance is intriguing - the just compensation awarded is therefore not motivated by the victim, but by what the state can pay. This result appears almost counterintuitive. But if we consider this from the perspective of the institution of the Court, perhaps the approach is not surprising: the European Court is overwhelmed with applications. On average, the Court received between 61,100 applications per year between 2010 and $2017 .{ }^{219}$ Even more importantly, most of the applications received involve repetitive violations against the same countries. The desire to rid itself of these cases, to wipe them from the docket, is more than understandable. From the perspective of the institution, it might even be crucial for the survival of the Court. ${ }^{220}$ In this regard, all but one judge underlined that the cases before it are 'not about money'; indeed, compensation is merely 'symbolic'. ${ }^{221}$ This symbolism and discretion the Court enjoys in the setting of just satisfaction under Article 41 allows judges to set the quantum by paying regard to other goals, such as compliance and docket control, rather than the victim.

\section{The Two Models Compared: The IrReleVAnt VIC- TIM AND THE STATE'S INFLUENCE ON DAMAGES}

The data analysis reveals a discrepancy between what the Court says it is doing and what is in fact happening. They show that the victim is wholly neglected in the Court's consideration of damages. Her vulnerability, individual circumstances and consequences she may have suffered are mostly ignored (including death). In group cases, the award is not individualised and the victim depends on others in the group. ${ }^{222}$ As I mentioned above, the results of the regression analysing reveal that the victim model explains only between $0-5 \%$ of the variability in the award of just satisfaction. The result suggests that the victim is clearly not at the centre of the Court's analysis. Although the Court, whose main is to deliver individual justice and who insists its aim in awarding damages is to compensate the victim for their pain and suffering, this is clearly not understood in subjective terms or by paying attention to the particular circumstances of the victim.

In contrast to the victim model, the state model can explain at least twice as much of variability in the data as variables related to the victim (up to an additional 15\% of variability in the data). ${ }^{223}$ It is striking that all state variables have a significant impact on the determination of the quantum: the identity of the country, the qualification of state conduct and the measurement of the frequency of such conduct. The Court appears to be focusing on state conduct and determines damages depending on how that conduct has been qualified (e.g. as torture, inhuman or degrading treatment). Damages for torture/excessive force/arbitrary detention are considerably elevated and adjusted on the basis of the country's GDP. In principle, therefore, rich countries pay more for the same type of behaviour than poor countries. Although the Court asserts it is seeking to ensure equal purchasing power of the victim across all violations, this appears true only to a limited extent (eg with certain type of behaviour, like poor conditions,

\footnotetext{
${ }^{219}$ European Court of Human Rights, 'The ECHR in facts and figures 2017' (2018) 5.

${ }^{220}$ The Court regularly receives threats from states that they may withdraw funding if decisions do not suit the respondents. The Court is naturally sensitive to these threats and, as some have argued, may be internalizing the discontent of states by adapting its approach to rights. As Helene Tigroudja put it: 'The Court is paralysed by the fear of non-compliance.' Hauser 25 $5^{\text {th }}$ Anniversary, NYU Law School, 11 October 2019, https://www.law.nyu.edu/global/globalevents/hauser25th.

${ }^{221}$ Interviews with ECtHR Judges 27 and 30, February 2018.

${ }^{222}$ In addition, applicant's contribution appears to have no bearing on the awards made, although the Court asserts that it will not provide damages to terrorists or others who have contributed to their situations. Eg Article 2, McCann case, app.no. 18984/91, 27 September 1995.

${ }^{223}$ Though if awards are not given in a logarithmic form, the state variables can explain much more of the variability in the data, up to $40 \%$.
} 
remaining similarly priced across different GDPs). Finally, if the Court is seeking to dissuade systemic violators of human rights, the regression analysis suggests that only up to 27 Euros extra in Article 3 is paid for every additional violation the Court has found against that country in its docket. In Article 5 cases, this number is negative, suggesting that frequent violators get a discount on quantity in order to facilitate easier compliance with numerous ECtHR decisions.

There are of course a number of problems with the approach uncovered. First, if the general image of the ECtHR is one of a forum available to every human rights victim - to hear her claim and to redress the violation, the results clearly show that although access to the Court may be about the victim, damages most certainly are not. Instead, there is a clear shift from the victim to the state - what it might be able to pay or what it may be able to comply with. This differs greatly from the individual justice narrative the Court is trying to portray about itself. In fact, it almost reminds of the arguments made by Laurence Helfer in his EJIL article on the embeddedness of the ECtHR framework into the domestic framework. ${ }^{224}$ Helfer argues that the Court has to look for new ways in which it can work with states and state organs to facilitate the embeddedness of the Convention into the domestic legal system. This includes looking for innovative and state-specific measures to address human rights violations in specific jurisdictions and to help these states - through domestic courts and governments - redress human rights violations themselves. ${ }^{225}$ Though Helfer talks mostly about subsidiarity and the margin of appreciation, the discounts used to facilitate payment of just satisfaction may also be one tool (though unexpected) to help states with compliance with the ECtHR.

It is an open question whether the Court is correct to reduce just satisfaction in cases involving frequent violators with the aim to facilitate compliance. ${ }^{226}$ I have argued elsewhere that the Court's approach goes against much of behavioural economics literature, which instead recommends the use of punitive damages to motivate states to change their behaviour. ${ }^{227}$ Practitioners appearing before the Court similarly argue that low damage amounts together with states' belief that the payment of compensation concludes the case, mean that the system contains no real incentive to motivate states to address and remove systemic problems at home. Instead, the payment of damages frequently means that for states the issue is resolved and the 'door is closed'. Often, however, the underlying problem still remains and generates new repetitive cases. The question therefore remains as to whether the Court in its approach to damage-setting should be concerned with compliance and whether by making repetitive violations cheaper, it is enabling frequent violators to 'pay off' their behaviour more easily and failing to deter future violations.

The second problem uncovered by the study is that the position of the victim is further undermined by information asymmetry about the potential remedies. By keeping the scales according to which damages are calculated secret, the Court is putting a disproportionate burden on the victims. Victims have to invest disproportionate amounts of time and effort (as well as money) to bring their claims to the Court. Often, they are unaware of how small the damage amounts will be. In contrast, States who appear frequently before the Court know precisely and accurately how much a certain type of behaviour may cost. Torture costs about 20000 Euros, a disappearance 60000 Euros, and arbitrary detention - depending on the respective paragraph of Article 5 between 25 Euros a day and 500 Euros a day. As I have argued elsewhere, some countries are aware of the type of cases coming through the pipeline of the Court and are able to 'plan' how much the violations will cost. An intriguing example of such behaviour is Russia,

\footnotetext{
${ }^{224}$ Helfer (n 15).

225 Ibid., $141 \mathrm{ff}$.

${ }^{226}$ To my knowledge, the Court currently does not have the empirical data to assess whether and in which cases lower damage amounts lead to better compliance.

${ }^{227}$ Fikfak (n 1) EJIL Article.
} 
which is one of the worst systemic violators of the ECHR (together with Turkey, Romania and Ukraine). Russian legislation explicitly requires that the country's annual budget contains a part intended to pay off ECHR violations. ${ }^{228}$ Between 2010 and 2016, the amount 'reserved' for ECHR compensation was respectively 114 million rubles (US $\$ 1.7$ million) and 500 million rubles (US \$7.6 million). ${ }^{229}$ Although we cannot conclude from this that Russia 'plans' its violations in advance, the budgeting clearly reveals that Russia is able to calculate in advance how much ECtHR violations will cost in a given year. The same cannot be said of victims of human rights violations. As a rule, they remain ignorant of the low amounts of compensation and if offered friendly settlement, are often unable to assess whether the offer made is comparable to prior cases or not. ${ }^{230}$ The publication of the scales according to which damage amounts are calculated (which the Court has thus far resisted) would go some way towards addressing this information asymmetry.

Whilst the current practice of the Court in relation to damages is to a large extent dictated by precedent and scales, which have sought to consolidate this precedent into consistent practice, this year the Court is embarking on a revision of its just satisfaction practice. ${ }^{231} \mathrm{Im}$ portant voices within the Court have suggested changes to its approach. ${ }^{232}$ Let us hope that the current practice - though understandable from an execution/compliance perspective - can be revisited in order to redress the potential commodification of human rights, which this study has revealed.

\footnotetext{
${ }^{228}$ Federal Law no. 359-FZ on the Federal Budget for 2016, 14 December 2015, Art. 21(5).

${ }^{229}$ Note that Russia has rejected compliance with Yukos v. Russia following a decision of its Constitutional Court and 'compensation reserve' in the budget does not therefore refer to that decision. ECtHR, Yukos v. Russia, Appl. no. 14902/04, Judgment of 20 September 2011. See Decision of the Russia Constitutional Court 19 January 2017, available in documents submitted to the Committee of Ministers, Doc. DH-DD(2017)207 (2017).

${ }^{230}$ Note that friendly settlements are becoming increasingly frequent and in relation to certain countries represent up to $50 \%$ of all cases. V. Fikfak, 'Against Settlement before the ECtHR' (forthcoming). Also H. Keller et al Friendly Settlements before the European Court of Human Rights (OUP, 2010).

${ }^{231}$ This was confirmed in several interviews with judges (Judges 19, 22, 24), February/March 2018.

232 Pinto and van Aaken (n 87).
} 


\section{ANNEX:}

\section{DESCRIPTION OF VARIABLES, MODELS AND REGRESSION ANALYSIS RESULTS}

\section{A. Coding and Description of variables}

\section{General coding for all three articles}

\begin{tabular}{ll} 
Award & Award in Euros \\
\hline Also provided $\log A$ ward & Award in logarithmic form \\
Claim NP & Whether claim for non-pecunairy damage made \\
\hline 0 & The applicant made no claim for damages \\
1 & The applicant made a specific claim for damages \\
2 & The applicant left the determination of quantum to the Court
\end{tabular}

VICTIMquantum Exact quantum requested

Also provided VICTIMquantumlog Claim for quantum in logarithmic form ${ }^{234}$

VICTIMage Age of the victim at the time decision rendered

\begin{tabular}{ll} 
VICTIMgender & Gender \\
\hline 0 & Male \\
1 & Female
\end{tabular}

\begin{tabular}{cl} 
VICTIMvulnerab & Vulnerability \\
\hline 0 & None \\
1 & Vulnerable
\end{tabular}

VICTIMnoingroup Precise number of victims in case (for which violation found)

\footnotetext{
233 The variable is skewed to the right, therefore we generated a new variable $\log (\mathrm{Award}+1)$.

${ }^{234}$ The variable is skewed to the right, therefore we generated a new variable $\log$ (VICTIMquantum +1 ), to include also cases in which the applicants have left it to the discretion of the Court to determine quantum.
} 
1

2
Old countries (accession Austria, Belgium, Cyprus, Denmark, Finbefore 1989) land, France, Germany, Greece, Italy, Malta, Netherlands, Portugal, Spain, Sweden, Switzerland, United Kingdom

Albania, Azerbaijan, Bulgaria, Croatia, Czech Republic, Georgia, Hungary, Latvia, Lithuania, Republic of Moldavia, Poland, Romania, Russian Federation, Slovak Republic, Slovenia, The former Yugoslav Republic of Macedonia, Ukraine

STATEsystemic Number of cases in the cohort which violation of Article 3 was found against the respondent State

\section{Specific coding for each article}

a) Article 3-Torture, inhuman and degrading treatment

VICTIMseriousC Serious consequences suffered by victim as a result of violation

0

None

1

Death

2

Other permanent or serious damage (loss of limb/injury or chronic illness)

STATEConduct

STATEArt3 Number of Article 3 violations the applicant suffered which are qualified as ill-treatment

STATEitdt Number of inhuman and degrading treatment violations the applicant suffered

STATEInhuman Number of inhuman treatment violations the applicant suffered

STATETorture Number of torture violations the applicant suffered

STATEDegrading Number of degrading treatment violations

STATEPositive Number of positive obligation violations the applicant suffered

STATEEffective Number of lack of effective investigation violations the applicant suffered

b) Article 2-Right to life 
Also provided APPquantumlog Claim for quantum in logarithmic form ${ }^{235}$

APPRelationshipwVIC Applicant's relationship with victim

1

Applicant is victim's Partner

2

Children

3

Parents

4

Brother/sister

5

Other

6

Multiple victims

APPage

Age of the applicant at the time decision rendered

\begin{tabular}{cc} 
APPgender & Gender \\
\hline 0 & Male \\
1 & Female
\end{tabular}

APPnoingroup Precise number of applicants in case (for which violation found)

APPIndividualcircs Applicant's specific circumstances

$1 \quad$ Financial dependence on victim

$2 \quad$ Health problems

$3 \quad$ Other

VICTIMDeceased Is the victim deceased?

$0 \quad$ None

$1 \quad$ Death

VICTIMContribution Did the victim contribute to their situation?

$0 \quad \mathrm{No}$

$1 \quad$ Yes

235 The variable is skewed to the right, therefore we generated a new variable $\log$ (VICTIMquantum +1 ), to include also cases in which the applicants have left it to the discretion of the Court to determine quantum. 
STATEUnexplained Whether the victim suffered unexplained death in violation of Article 2 STATEDisappearance Whether the victim disappeared in violation of Article 2

STATEIntentionalK Whether the victim was intentionally killed in violation of Article 2

STATEExcessivefor Whether excessive force was used against the victim in violation of Article 2

STATEDutytoprotect Number of times the duty to protect was not abided in violation of Article 2

STATEEffective Number of lack of effective investigation violations the applicant suffered

c) Article 5-Indefinite detention

VICTIMConvicted Was the victim convicted of crime?

$0 \quad$ No

$1 \quad$ Yes

STATEConduct

STATEArticle51 Number of violations of Article 5-1 against the applicant

STATEArticle52 Number of violations of Article 5-2 against the applicant

STATEArticle53 Number of violations of Article 5-3 against the applicant

STATEArticle54 Number of violations of Article 5-4 against the applicant

STATEArticle55 Number of violations of Article 5-5 against the applicant 


\section{B. Models}

\begin{tabular}{|c|c|c|c|c|}
\hline Variables & $\begin{array}{l}\text { Model } \\
\text { Prelim }\end{array}$ & $\begin{array}{l}\text { Model Vic- } \\
\text { tim }^{*}\end{array}$ & $\begin{array}{l}\text { Model } \\
\text { State }\end{array}$ & $\begin{array}{l}\text { Model To- } \\
\text { gether }\end{array}$ \\
\hline Whether claimed NP damages? & $X$ & & & $\mathrm{X}$ \\
\hline Victim: Age & & $\mathrm{X}$ & & $\mathrm{X}$ \\
\hline Victim: Gender & & $\mathrm{X}$ & & $\mathrm{X}$ \\
\hline Victim: Vulnerability & & $\mathrm{X}$ & & $\mathrm{X}$ \\
\hline Victim (A2): Relationship applicant & & $\mathrm{X}$ & & $\mathrm{X}$ \\
\hline Victim (A2): Deceased & & $\mathrm{X}$ & & $\mathrm{X}$ \\
\hline Victim (A2): Individual circumstances & & $X$ & & $\mathrm{X}$ \\
\hline Victim $(A 2,5):$ Individual contribution & & $\mathrm{X}$ & & $\mathrm{X}$ \\
\hline Victim (A3): Serious consequences & & $\mathrm{X}$ & & $\mathrm{X}$ \\
\hline Victim (A3): Convicted & & $X$ & & $\mathrm{X}$ \\
\hline Victim: Solo or in group & & $\mathrm{X}$ & & $\mathrm{X}$ \\
\hline State: Country (old, new, Turkey) & & & $\mathrm{X}$ & $\mathrm{X}$ \\
\hline State: Systemic violation & & & $\mathrm{X}$ & $\mathrm{X}$ \\
\hline State: Legal qualification of conduct & & & $\mathrm{X}$ & $\mathrm{X}$ \\
\hline State: Effective investigation & & & $X$ & $\mathrm{X}$ \\
\hline State: Other positive obligation & & & $\mathrm{X}$ & $\mathrm{X}$ \\
\hline
\end{tabular}

*In Article 2, where the majority of the victims are deceased, the applicant is claiming compensation for their own pain and suffering due to the deprivation of life of a relative (ie victim). In this regard, in the context of Article 2, I use an additional model to determine the role of the applicant (who makes the claim). This is in addition to the model which investigates the role of the victim (relative who is deceased).

\section{Regression analysis results}

I use multiple regression analysis to examine the relationship between the amount awarded in moral damages and the different aspects of the case, namely variables related to the victim, to the state, and whether the victim made a claim. The different models are therefore defined as follows:

$$
\log (\text { Award }+1)=\beta 0+\beta 1 x_{1 i}+\cdots+\beta k x k i+e i, \mathrm{i}=1, \ldots, \mathrm{n}
$$


The dependent variable (amount awarded in respect of non-pecuniary damage) is the natural logarithm of the amount. The logarithmic transformation is used because the award distribution is skewed to the right (as the graphs below suggest) and it makes the distribution more normal. ${ }^{236}$

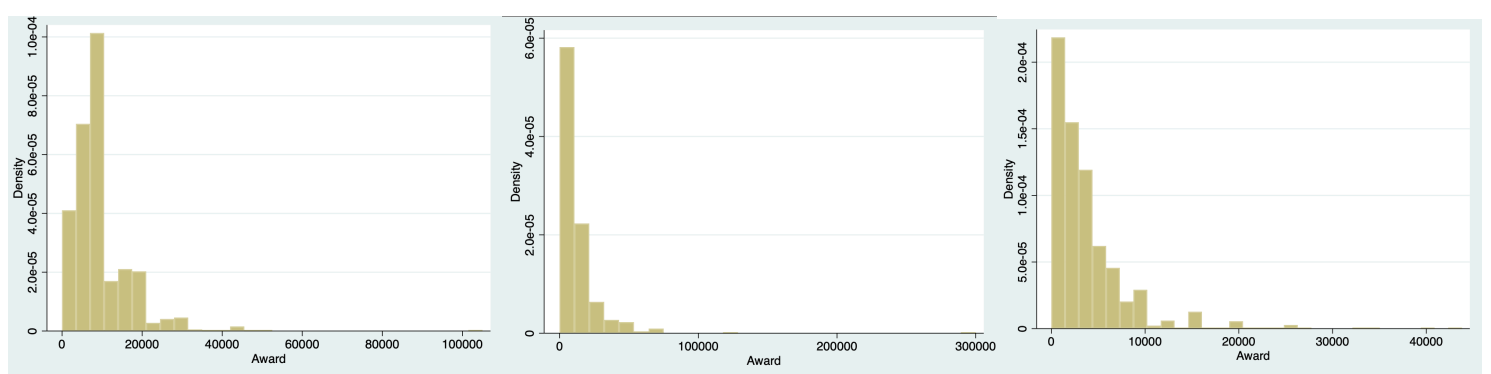

Graphs picturing awards in Article 3, Article 2 and Article 5 cases respectively

The subscript $i$ refers to the individual victims in the selected sample of $n$ victims. The key independent variables are explained in the next sections in relation to each of the articles. The coefficients to be estimated are the $\beta \mathrm{s}$, and $e$ is an error term.

In addition to the linear regression, I also use a multilevel random intercepts model to control for the variation depending on the case (indicated by subscript $j$ ). Such a model allows for the error term to feature a set differences for all victims within each higher level unit (cases). Independent variables at level 1 are those marked by $X$, whilst $Z$ are level 2 variables (case variables, which include variables: Country, STATEsystemic and number of victims in group).

$$
\log (\text { Award }+1)=\beta 1 x_{1 i j}+\beta 1 Z_{1 j} \cdots+\mu_{\mathrm{j}}+e_{i j}, \mathrm{i}=1, \ldots, \mathrm{n}
$$

\section{Article 3}

The linear regressions in relation to Article 3 employ four models. The first one tests to what extent the sole action of claiming compensation can explain the variability in data. The second model, victim model, looks to variables associated with the victim. In this regard, I look at how much the victim asked for (including whether they left the determination to the discretion of the Court), their age and gender, their vulnerability, whether they appear in a group or on their own and what consequences they have suffered. This is followed by a state model, which looks to the variables associated with the state. In both victim and state models, I do not include the 'whether they claimed' variable, but instead I only include those cases in which a claim was made (thus the reduced number of cases). This is to get more precise results about how much variables related to the victim/state may have affected their quantum, independent of whether they claimed variable. In this regard, the victim model contains also the quantum variable, which indicates how victims assessed their loss. Finally, I put all models together to see how the variables interact when all are considered together.

236 J. Wooldridge, Introductory Econometrics: a Modern Approach (2013) 191-4. 


\begin{tabular}{|c|c|c|c|c|}
\hline Variable & Prelim1 & Victim1 & State1 & Together 1 \\
\hline \multicolumn{5}{|l|}{ ClaimNP } \\
\hline 1 & $7.578 * * *$ & & & $7.556 * * *$ \\
\hline 2 & $7.855 * * *$ & & & $7.900 * * *$ \\
\hline VICTIMquantumlog & & $0.030 *$ & & \\
\hline VICTIMage & & 0.001 & & -0.005 \\
\hline \multicolumn{5}{|l|}{ VICTIMgender } \\
\hline 1 & & 0.096 & & 0.052 \\
\hline VICTIMvulnerab & & -0.102 & & 0.017 \\
\hline VICTIMnoingroup & & $-0.003 *$ & & -0.000 \\
\hline \multicolumn{5}{|l|}{ VICTIMSeriousC } \\
\hline 1 & & 0.166 & & 0.697 \\
\hline 2 & & 0.550 & & 0.498 \\
\hline \multicolumn{5}{|l|}{ Country } \\
\hline 2 & & & $-0.544 * * *$ & $-0.508 * * *$ \\
\hline 3 & & & $-0.598 * * *$ & $-0.813 * * *$ \\
\hline STATEsystemic & & & $0.003 * * *$ & $0.004 * * *$ \\
\hline STATEArt3 & & & $0.353 * * *$ & $0.377 * * *$ \\
\hline STATEitdt & & & $0.675 * * *$ & $0.847 * * *$ \\
\hline STATEInhuman & & & $0.254 *$ & $0.470 * *$ \\
\hline STATETorture & & & $1.357 * * *$ & $1.358 * * *$ \\
\hline STATEDegrading & & & $0.370 * * *$ & $0.341 *$ \\
\hline STATEPositive & & & $0.334 *$ & 0.265 \\
\hline STATEEffective & & & $0.391 * * *$ & $0.504 * * *$ \\
\hline Constant & $1.341 * * *$ & $8.644 * * *$ & $8.530 * * *$ & $0.993 * * *$ \\
\hline $\mathrm{N}$ & 1128 & 969 & 1064 & 1033 \\
\hline r2_a & 0.677 & 0.006 & 0.150 & 0.714 \\
\hline
\end{tabular}

The results in the regression analysis clearly show that in addition to whether they claimed, variables connected to the state are the best indicators of the awards made (they can explain $67 \%$ and $15 \%$ respectively of the data). The final model shows that in addition to whether a victim claimed compensation, only variables related to the state have a significant impact on the quantum awarded. Specifically, they show that new countries and Turkey pay substantially less in compensation.

The results were also tested in a multilevel model, which controls for the fact that the Court considers cases not victims. This suggests that the best fit model is the state model (smallest $2 \log$ likelihood and BIC, given the number of cases). The significance of variables does not change considerably, though the quantum claimed by the victim and the appearance in group rather than individually become insignificant.

\section{Article 2}

The linear regressions in relation to Article 2 employ five models. The first one tests to what extent the sole action of claiming compensation can explain the variability in data. The second model, the applicant model, investigates how much variables associated with the applicant, ie the relative claiming for their own pain and suffering after the death of the victim, can explain the variability in data. This is different from the victim model. First, how the applicant assesses their own pain and suffering in this context will depend also on how they value the relative's life. In this regard, it looks to who the applicant is (gender and age) and what his relationship was to the victim, it considers the individual circumstances in which the applicant finds himself after the death of the victim (financial dependence, health issues or other), and whether the applicant claims on their own or in a group. The second model then looks at the victim and to variables associated with the victim. In this regard, I look at whether the victim is deceased, 
whether they were defined as vulnerable and whether they contributed to their situation. This is then followed by a state model, which looks to the variables associated with the state. As before, in applicant, victim and state models, I do not include the 'whether they claimed' variable, but instead I only include those cases in which a claim was made (thus the reduced number of cases). This is to get more precise results about how much variables related to the victim/state may have affected their quantum, independent of whether they claimed variable. In this regard, the applicant model contains also the quantum variable, which indicates how they assessed their loss. Finally, I put all models together to see how the variables interact when all are considered together.

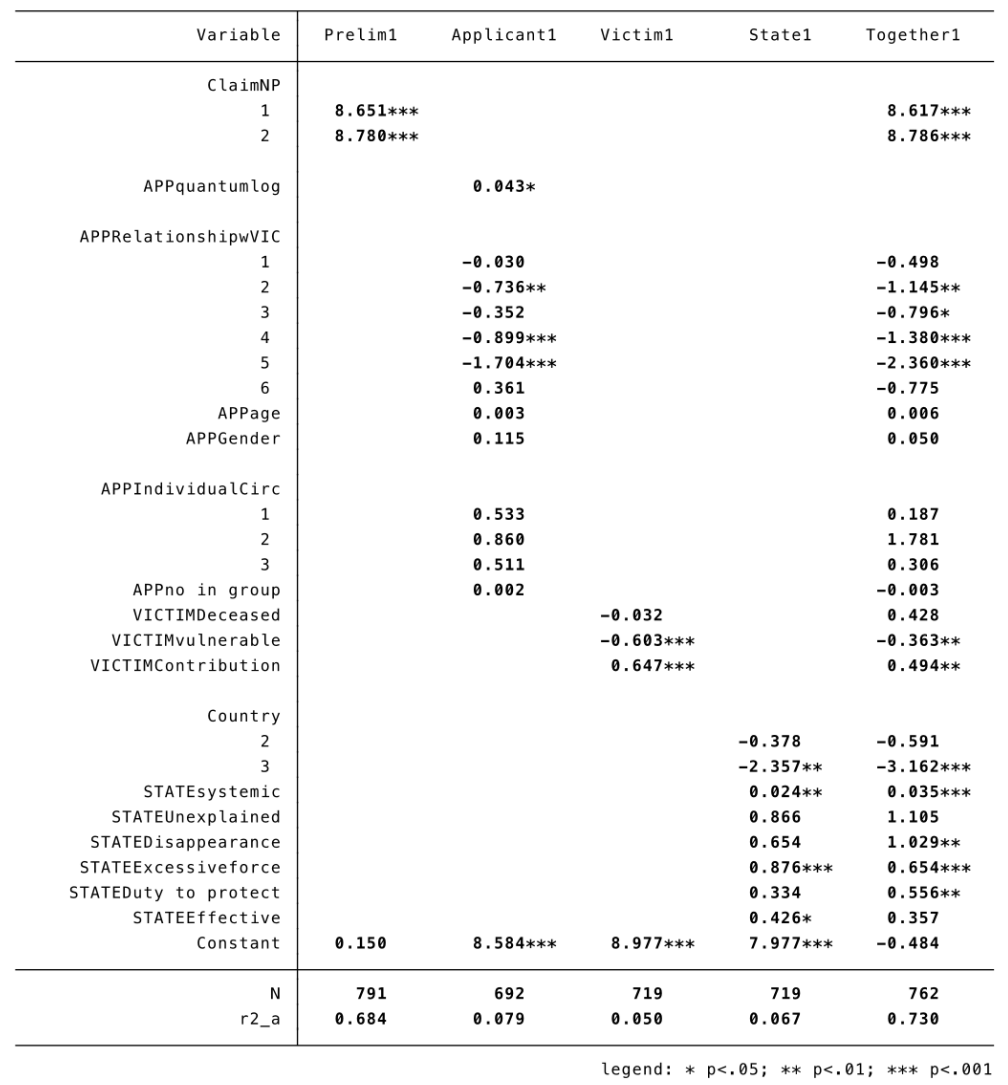

The results in the regression analysis clearly show that in addition to whether they claimed, variables connected to the applicant and to the state are the best indicators of the awards made (they can explain $68 \%, 8 \%$ and $6,7 \%$ respectively of the data). The final model shows that in addition to whether a victim claimed compensation, the applicant's relationship to the victim and variables related to the state have a significant impact on the quantum awarded. Specifically, they show that Turkey pays substantially less in compensation than old, rich countries.

The multilevel model suggests that the best fit model is either the applicant model or the state model (smallest-2loglikelihood and BIC, given the number of cases). There is some change to the significance of variables - although Turkey still pays less, this appears to be not significant (ie Turkey), whilst financial dependance of the victim becomes relevant in the multilevel model. 


\section{Article 5}

The linear regressions in relation to Article 5 employ four models. The first one tests to what extent the sole action of claiming compensation can explain the variability in data. The second model, victim model, looks to variables associated with the victim. In this regard, I look at how much the victim asked for (including whether they left the determination to the discretion of the Court), ${ }^{237}$ their age and gender, their vulnerability, whether they appear in a group or on their own and whether they were convicted (ie to test whether convicted individuals vs others who have not yet been convicted are treated differently). This is followed by a state model, which looks to the variables associated with the state. In both victim and state models, I do not include the 'whether they claimed' variable, but instead I only include those cases in which a claim was made (thus the reduced number of cases). This is to get more precise results about how much variables related to the victim/state may have affected their quantum, independent of whether they claimed variable. Finally, I put all models together to see how the variables interact when all are considered together.

\begin{tabular}{|c|c|c|c|c|}
\hline Variable & Prelim1 & Victim1 & State1 & Together 1 \\
\hline \multicolumn{5}{|l|}{ ClaimNP } \\
\hline 1 & $7.085 * * *$ & & & $7.455 * * *$ \\
\hline 2 & $6.477 * * *$ & & & $6.874 * * *$ \\
\hline VICTIMquantumlog & & $0.106 * * *$ & & \\
\hline VICTIMAge & & -0.006 & & -0.002 \\
\hline \multicolumn{5}{|l|}{ VICTIMGender } \\
\hline 1 & & 0.242 & & 0.188 \\
\hline No in group & & 0.018 & & 0.003 \\
\hline VICTIMconvicted & & -0.250 & & -0.161 \\
\hline VICTIMVulnerab & & 0.166 & & 0.032 \\
\hline \multicolumn{5}{|l|}{ Country } \\
\hline 2 & & & $-0.807 * * *$ & 0.277 \\
\hline 3 & & & -0.344 & $1.193 * * *$ \\
\hline STATEsystemic & & & $0.006 * * *$ & $-0.005 * * *$ \\
\hline STATEArticle 51 & & & $1.497 * * *$ & $0.967 * * *$ \\
\hline STATEArticle 52 & & & -0.701 & -0.721 \\
\hline STATEArticle53 & & & 0.287 & $0.584 * * *$ \\
\hline STATEArticle54 & & & $0.416 * *$ & 0.015 \\
\hline STATEArticle 55 & & & -0.028 & -0.042 \\
\hline Constant & 0.223 & $6.834 * * *$ & $6.352 * * *$ & -0.459 \\
\hline $\mathrm{N}$ & 1247 & 1034 & 1139 & 1138 \\
\hline r2_a & 0.421 & 0.021 & 0.108 & 0.558 \\
\hline
\end{tabular}

The results in the regression analysis clearly show that in addition to whether they claimed, variables connected to the state are the best indicators of the awards made (they can explain $42 \%$ and $11 \%$ respectively of the variability in the data). The final model shows that in addition to whether a victim claimed compensation, variables related to the state have a significant impact on the quantum awarded. Interestingly, they show that Turkey pays substantially more in compensation than old, rich countries.

The multilevel model suggests that the best fit model is either the state or the together model (smallest -2loglikelihood and BIC, given the number of cases). There is no change to significance of variables.

${ }^{237}$ This variable is excluded in the together model because the other variable ClaimNP is included. 